\title{
Pituitary adenylate cyclase activating polypeptide as a novel hypophysiotropic factor in fish
}

\author{
Anderson O.L. Wong, Wen Sheng Li, Eric K.Y. Lee, Mei Yee Leung, Lai Yin Tse, \\ Billy K.C. Chow, Hao Ren Lin, and John P. Chang
}

\begin{abstract}
Pituitary adenylate cyclase activating polypeptide (PACAP) is a novel member of the secretin-glucagon peptide family. In mammals, this peptide has been located in a wide range of tissues and is involved in a variety of biological functions. In lower vertebrates, especially fish, increasing evidence suggests that PACAP may function as a hypophysiotropic factor regulating pituitary hormone secretion. PACAP has been identified in the brain-pituitary axis of representative fish species. The molecular structure of fish PACAP is highly homologous to mammalian PACAP. The prepro-PACAP in fish, however, is distinct from that of mammals as it also contains the sequence of fish GHRH. In teleosts, the anterior pituitary is under direct innervation of the hypothalamus and PACAP nerve fibers have been identified in the pars distalis. Using the goldfish as a fish model, mRNA transcripts of PACAP receptors, namely the PAC1 and VPACl receptors, have been identified in the pituitary as well as in various brain areas. Consistent with the pituitary expression of PACAP receptors, PACAP analogs are effective in stimulating growth hormone (GH) and gonadotropin (GTH)-II secretion in the goldfish both in vivo and in vitro. The GH-releasing action of PACAP is mediated via pituitary PACl receptors coupled to the adenylate cyclase-cAMP-protein kinase A and phospholipase C-IP3-protein kinase $\mathrm{C}$ pathways. Subsequent stimulation of $\mathrm{Ca}^{2+}$ entry through voltage-sensitive $\mathrm{Ca}^{2+}$ channels followed by activation of $\mathrm{Ca}^{2+}$-calmodulin protein kinase II is likely the downstream mechanism mediating PACAP-stimulated GH release in goldfish. Although the PACAP receptor subtype(s) and the associated post-receptor signaling events responsible for PACAP-stimulated GTH-II release have not been characterized in goldfish, these findings support the hypothesis that PACAP is produced in the hypothalamus and delivered to the anterior pituitary to regulate GH and GTH-II release in fish.
\end{abstract}

Key words: PACAP, VIP, PAC1 receptor, VPAC1 receptor, VPAC2 receptor, growth hormone, gonadotropin-II, cAMP, protein kinase A, protein kinase $\mathrm{C}$, calcium, pituitary cells, goldfish, and teleost.

Résumé : Le polypeptide activant l'adénylate cyclase hypophysaire (PACAP) est un nouveau membre de la famille de peptides sécrétine/glucagon. Chez les mammifères, ce peptide se trouve dans plusieurs tissus et il intervient dans divers processus biologiques. Chez les vertébrés inférieurs, spécialement chez les poissons, plusieurs éléments suggèrent que le PACAP serait un facteur hypophysiotrope réglant la sécrétion d'hormones hypophysaires. Le PACAP a été identifié dans le cerveau et l'hypophyse d'espèces représentatives de poissons. La structure moléculaire du PACAP des poissons est très homologue à celle du PACAP des mammifères. Cependant, le prépro-PACAP des poissons est différent de celui des mammifères, puisqu'il comporte également la séquence de la somatocrinine (GHRH) de poissons. Chez les téléostéens, l'antéhypophyse est innervée directement par l'hypothalamus et des fibres nerveuses à PACAP ont été mises en évidence dans l'antéhypophyse. Des ARNm des récepteurs PACl et VPACl, des récepteurs du PACAP, ont été mis en évidence dans l'hypophyse et diverses régions du cerveau du cyprin doré. En concordance avec l'expression de récepteurs du PACAP dans l'hypophyse, des analogues du PACAP stimulent la sécrétion de l'hormone somatotrope

Received January 13, 2000. Revised March 15, 2000. Accepted March 15, 2000. Published on the NRC Research Press web site on May 2, 2000.

Abbreviations: PACAP, pituitary adenylate cyclase activiting polypeptide; VIP, vasoactive intestinal polypeptide; GHRH, growth hormone-releasing hormone; GnRH, gonadotropin-releasing hormone; GH, growth hormone; GTH-II, maturational gonadotropin; AC, adenylate cyclase; PLC, phospholipase C; cAMP, cyclic 3',5'-adenosine monphosphate; IP3, inositol 1,4,5-trisphosphate; DAG, diacylglycerol; PKA, protein kinase A; PKC, protein kinase C; CAM kinase II, $\mathrm{Ca}^{2+}-$ calmodulin-dependent protein kinase II; VSCC, voltage-sensitive $\mathrm{Ca}^{2+}$ channels.

A.O.L. Wong, ${ }^{1}$ E.K.Y. Lee, M.Y. Leung, L.Y. Tse, and B.K.C. Chow. Department of Zoology, University of Hong Kong, Pokfulam Road, Hong Kong.

W.S. Li and H.R. Lin. Department of Biology, Zhongshan (Sun Yet-Sen) University, Guangzhou, China.

J.P. Chang. Department of Biological Sciences, University of Alberta, Edmonton, AB, Canada.

'Author to whom all correspondence should be addressed (e-mail: olwong@hkucc.hku.hk). 
(GH) et de la gonadotrophine II (GTH-II) chez le cyprin doré in vivo et in vitro. Le PACAP stimule la libération de la GH par l'intermédiaire des récepteurs PAC1 hypophysaires couplés à la voie de l'adénylate cyclase, de l'AMPc et de la protéine kinase $\mathrm{A}$ et à la voie de la phospholipase $\mathrm{C}$, de l'inositol triphosphate et de la protéine kinase $\mathrm{C}$. La stimulation subséquente de l'entrée du $\mathrm{Ca}^{2+}$ par des canaux calciques voltage-dépendants et l'activation de la protéine kinase $\mathrm{Ca}^{2+}$ - calmoduline-dépendante II est probablement le mécanisme intervenant par la suite dans la stimulation de la libération de la GH par le PACAP chez le cyprin doré. Même si les sous-types de récepteurs du PACAP et les voies de signalisation entraînant la stimulation de la libération de la GTH-II par le PACAP ne sont pas encore connus chez le cyprin doré, ces résultats sont en accord avec l'hypothèse selon laquelle le PACAP est synthétisé dans l'hypothalamus, puis transporté dans l'antéhypophyse afin de régler la sécrétion de la GH et de la GTH-II chez le poisson.

Mots clés : PACAP, VIP, récepteur PAC1, récepteur VPAC2, hormone somatotrope, gonadotrophine II, AMPc, protéine kinase A, protéine kinase $\mathrm{C}$, calcium, cellules hypophysaires, cyprin doré, téléostéen.

[Traduit par la Rédaction]

\section{Introduction}

Pituitary adenylate cyclase activating polypeptide (PACAP) is a member of the secretin- glucagon-vasoactive intestinal polypeptide (VIP) family. This peptide was first isolated from ovine hypothalamus by its stimulatory action on adenylate cyclase activity in rat pituitary cells (Miyata et al. 1989). In mammals, two forms of PACAP have been identified, namely PACAP38 and PACAP27; both are biologically active (Miyata et al. 1989, 1990). PACAP38 is a 38 amino acid polypeptide with its N-terminal sequence highly homologous to VIP, whereas PACAP27 is a truncated form of PACAP38 containing only the first 27 amino acids. These two peptides are derived from the same precursor by posttranslational proteolysis and alternative $\alpha$-amidation through the actions of prohormone convertases ( $\mathrm{Li}$ et al. 1999). PACAP immunoreactivity is widely distributed in the central nervous system (CNS; Koves et al. 1994) and peripheral tissues, including the gut, pancreas, adrenal gland, and gonads (Arimura and Shioda 1995), with PACAP38 being the predominant form (Arimura et al. 1991). Consistent with its wide range of tissue distribution, PACAP is involved in a variety of biological functions. For example, the roles of PACAP as a neurotransmitter (Masuo et al. 1993) and neurotrophic factor (Lindholm et al. 1998) in CNS are well documented. At the peripheral level, PACAP is known to regulate blood flow (Carlsson et al. 1996), gut motility (Lauff et al. 1999), dilation of airways (Linden et al. 1999), insulin secretion from $\beta$ cells (Filipsson and Ahren 1998), steroidogenesis in the ovary (Zhong and Kasson 1994), and catecholamine release (Isobe et al. 1993) and synthesis (Park et al. 1999) in the adrenal medulla. Some recent studies also suggest that PACAP may play a role in regulating cytokine secretion (Jiang et al. 1998) and fine-tuning of the biological clock (Harrington et al. 1999). (For recent reviews, see Rawlings and Hezareh 1996; Arimura 1998).

Since the demonstration of its stimulatory effect on adenylate cyclase activity in rat pituitary cells (Miyata et al. 1989), extensive studies have been performed to elucidate the role of PACAP in regulating pituitary functions. In mammals, the role of PACAP as a hypophysiotropic factor is supported by the findings that: $i$ ) PACAP perikarya are located in the hypothalamus (Takahashi et al. 1994); ii) PACAP nerve fibers are present in the median eminence (Koves et al.
1994); iii) PACAP immunoreactivity can be detected in the hypophyseal portal blood (Dow et al. 1994); and iv) under certain conditions, PACAP stimulates secretion of pituitary hormones, including gonadotropins (GTH; Tsujii et al. 1994), growth hormone (GH; Goth et al. 1992), prolactin (PRL; Hart et al. 1992), and adrenocorticotropic hormone (ACTH; Propato-Mussafiri et al. 1992). Since the stimulatory actions of PACAP on pituitary hormone release are in general weak or modest, it has been proposed that this peptide is not a typical hypophysiotropic factor in mammals but rather a modulator of pituitary hormone secretion (Rawlings and Hezareh 1996). It is also worth mentioning that the physiological role of PACAP as a regulator of pituitary hormone release has not been fully established, as suppression of in vivo pituitary hormone secretion by blocking the action of endogenous PACAP has not been demonstrated. In recent years, the molecular structure of PACAP has been characterized in non-mammalian species, such as the bird (McRory et al. 1997), amphibian (Chartrel et al. 1991), and fish (McRory et al. 1995; Matsuda et al. 1997b). In particular, in teleost fish significant progress has been made in the understanding of PACAP gene structure (Parker et al. 1997). In this article, the recent advances in the studies of PACAP as a hypophysiotropic factor in fish will be discussed, with emphasis on the molecular cloning of fish PACAP and its receptors, their functional role in regulating $\mathrm{GH}$ and GTH-II release, as well as the post-receptor signaling mechanisms mediating $\mathrm{PACAP}$ regulation of $\mathrm{GH}$ synthesis and secretion.

\section{PACAP in fish: Molecular structure and evolution}

The molecular structure of PACAP is highly conserved among vertebrates. PACAP from mammals, including the rat (Ogi et al. 1990), mouse (Okazaki et al. 1995), sheep (Kimura et al. 1990), and human (Ohkubo et al. 1992), all share the same amino acid sequence. Using CD and NMR spectroscopy, the solution structures of ovine PACAP38 and PACAP27 have been elucidated (Wray et al. 1993). Ovine PACAP38 has three separate domains with the first eight amino acids in the N-terminus forming a disordered structure (position 1-8) followed by an extended central $\alpha$-helical region (position 9-26) and a short C-terminal $\alpha$-helical tail (postion 28-34). A flexible hinge at position 27 has been identified between the central $\alpha$-helical domain and $\mathrm{C}$ - 
terminal tail. The 3-D structure of ovine PACAP27 is similar to that of PACAP38 except that the C-terminal tail is missing (for review, see Wray et al. 1998). The N-terminal triplet His-Ser-Asp (position 1-3), central $\alpha$-helical domain (position 11-27), and C-terminal tail (position 28-32) form three anchorage sites for receptor recognition (Gourlet et al. 1995). Any two of these three structural domains can contribute to high affinity receptor binding. The $\mathrm{N}$-terminal triplet His-Ser-Asp, besides its role in receptor binding, is also essential for receptor activation and signal transduction, and its removal results in the production of competitive antagonists (e.g., PACAP6-38). PACAP have been isolated from non-mammalian species, including the frog (Chartrel et al. 1991), chicken (Yasuhara et al. 1992), teleost fish (Matsuda et al. 1997b), and more recently in elasmobranch (Matsuda et al. 1998a). In the frog, the amino acid sequence of PACAP38 is identical to that of mammalian PACAP38 except for a single substitution at position 35 where isoleucine is substituted for valine (Chartrel et al. 1991). PACAPs purified from the chicken (Yasuhara et al. 1992), stingray (Matsuda et al. 1998b), and stargazer (Matsuda et al. 1997a) are also highly homologous to the mammalian counterpart with little sequence variation in the first 27 amino acids and some minor substitutions in the C-terminus. Although NMR analysis has not been performed in non-mammalian PACAPs, it is expected that the 3-D structure of these peptides should be similar to that of mammalian PACAP.

The first non-mammalian PACAP was cloned in the brain of sockeye salmon by Sherwood's group (Parker et al. 1993). The deduced amino acid sequence of this PACAP cDNA reveals that the salmon prepro-PACAP is composed of a signal peptide, a cryptic peptide of unknown function, a 45 amino acid peptide with structural similarity to GHRH, and the amino acid sequence of PACAP38 (Fig. 1A). Given that the monobasic and dibasic cleavage sites are conserved in this fish prepro-PACAP, post-translational processing of this preprohormone is expected to generate mature peptides of PACAP27 and PACAP38, as well as the GHRH-like peptide. In subsequent studies, this GHRH-like peptide has been synthesized and found to stimulate $\mathrm{GH}$ release in coho salmon pituitary cells in vitro (Parker et al. 1997), suggesting that the associated peptide encoded in this PACAP cDNA is a salmon GHRH. These findings are different from the case in mammals in which PACAP and GHRH are encoded in two separate genes, and the corresponding region of mammalian PACAP cDNA encodes a peptide called PACAP-related peptide (PRP) with no known biological functions. In teleosts, GHRH has been purified from the common carp and shown to stimulate $\mathrm{GH}$ release in the goldfish (Vaughan et al. 1993) and rainbow trout (Luo and McKeown 1991). However, a separate gene for GHRH has not been previously reported in fish. PACAPs have also been cloned in the catfish (McRory et al. 1995), zebrafish (Fradinger et al. 1996), and more recently in the goldfish (Leung et al. 1999b). Similar to salmon PACAP cDNA, the coding sequence of a GHRH-like peptide is consistently located $5^{\prime}$ upstream of the PACAP coding region. The amino acids sequences of these fish PACAPs are highly homologous (> 90\%) to PACAPs reported in other vertebrates (Fig. 1B). In contrast, the sequences of the putative fish GHRHs are more variable (32$41 \%$ homology) except that the amino acids in the central core (position 11-24) are more conserved and comparable with the corresponding region of the mammalian GHRHs and PRPs (Fig. 1C). The genomic organization of fish PACAP genes has been recently elucidated and was found to consist of five exons and four introns (Parker et al. 1997). The coding sequence of fish PACAP is located in exon-V whereas the bulk of fish GHRH sequence is encoded in exon-IV. In contrast to PACAP genes in mammals which are known to have no CAAT and TATA boxes in the $5^{\prime}$ promoter (Hosoya et al. 1992), these cis-acting regulatory motifs are present in the fish PACAP gene promoter. In salmons, alternative splicing, in particular in the exon-IV region, has been reported to generate transcripts without the GHRH coding region (Parker et al. 1993). In our recent studies in the goldfish, two populations of PACAP mRNAs, a short form coding for PACAP only and a long form coding for both PACAP and GHRH, have been identified in the brain, pituitary, intestine, liver, and gonads (unpublished results, M.Y. Leung and A.O.L. Wong). These observations raise the possibility that PACAP and GHRH expression in fish can be differentially regulated.

Regarding the evolution of PACAP, it has been suggested that the ancestral gene may have originated from the glucagon gene family via exon duplication followed by gene duplication (Sherwood et al. 1994). More recently, the cDNAs and partial genes of PACAP27 have been cloned in the tunicate (Chelyosoma productum), an invertebrate closely related to the primitive chordate amphioxus (McRory and Sherwood 1997). Similar to fish PACAPs, tunicate PACAP27 is highly conserved in molecular structure and a GHRH-like peptide is also identified in the PACAP preprohormone. The expression of PACAP mRNA has been mapped to the neural gland of tunicates, suggesting that PACAP27 may serve as a neuropeptide in protochordates. In the same study, Southern blots of genomic DNA from a range of representative species were performed and PACAP hybridization signals were found in sea urchin, tunicate, reedfish, teleosts, and all tetrapod examples tested, but not in bacteria, yeast, or drosophila. These findings suggest that PACAP genes may have appeared first in echinoderms and evolved along the deuterostome line of evolution. In this case, PACAP genes in teleost fish completed the process of exon duplication, with one of the exons (i.e., the PACAPcoding exon) being highly conserved as a result of stringent selection, whereas the duplicated exon (i.e., the GHRHcoding exon) exhibited structural variability due to a lower selection pressure. Recently, the gene of chicken PACAP has been cloned. Surprisingly, the organization of chicken prepro-PACAP is rather similar to that of teleost fish with PACAP and GHRH being encoded inn the same gene (McRory et al. 1997). The splitting of separate PACAP and GHRH genes as a result of gene duplication may have been a recent event occurring immediately before the evolution of mammals.

\section{Hypophysiotropic actions of PACAP in fish}

\section{Tissue distribution of PACAP in fish: Implications of} biological functions

In teleosts, PACAP immunoreactivity has been identified in the nerve fibers of the enteric nervous system (Olsson and 
$\mathbf{A}$

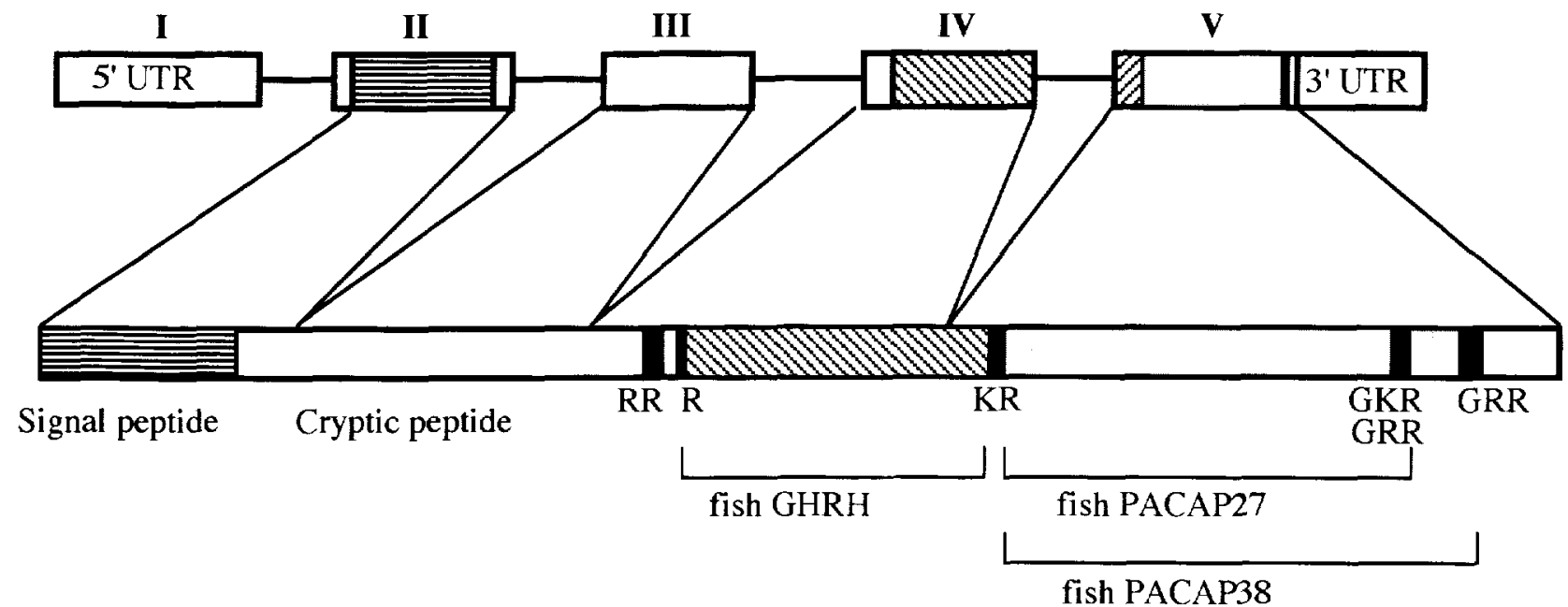

B

Goldfish PACAP38a Goldfish PACAP38b Catfish PACAP38 Stargrazer PACAP38 Chicken PACAP38 Stingray PACAP38 Human PACAP38 Ovine PACAP38 Rat /Mouse PACAP38 Frog PACA P38 Salmon PACAP38 Zebrafish PACAP38

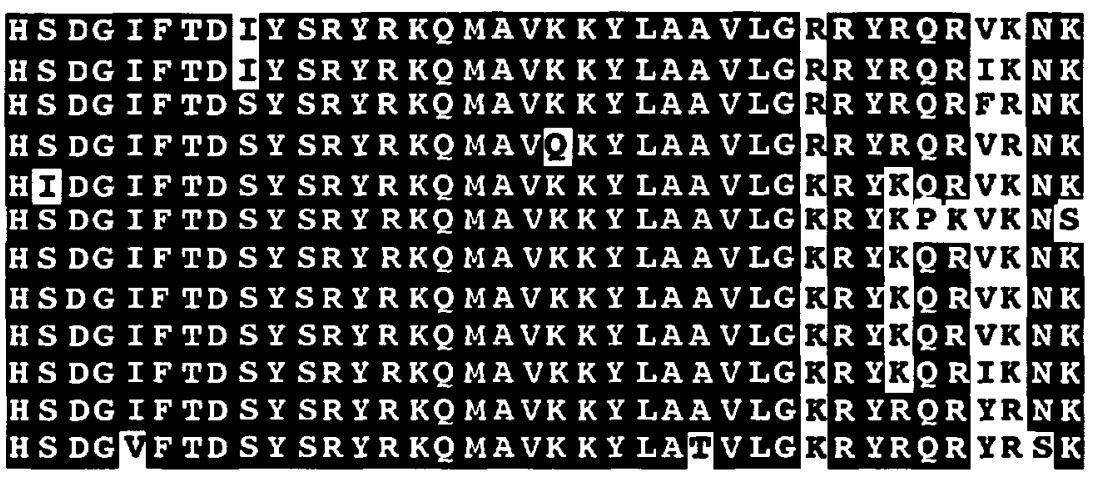

C

Mouse PRP
Rat PRP
Human PRP
Sheep PRP
Chicken GHRH1
Chicken GHRH2
Goldfish GHRH
Catfish GHRH
Carp GHRH
Zebrafish GHRH
Salmon GHRH
Sturgeon GHRH
Goat/Cow GHRH
Ovine GHRH
Hamster GHRH
Pig GHRH
Human GHRH
Rat GHRH
Mouse GHRH

Mouse PRP Chicken GHRH1 Chicken GHRH2 Goldfish GHRF Carp GHRH Zebrafish GHRH Salmon GHRH Sturgeon GHRH Ovine GHRH Pig G Rat GHRH Holmgren 1994) as well as the endocrine component of the fish pancreas (Jonsson 1995). Recently, ovine PACAP27 and PACAP38 were shown to inhibit spontaneous contraction in the gut of Atlantic cod (Olsson and Holmgren 1998),

DVAHEIIN EA YR KVIDQLSARKYIQS VVAR GACDEP RR HA VDDPAPIT . DVAHEI IN EA YR KVIDQL SARK YL QS MVAR GMGENI AA AA VDDRAP IT . DVARG I IN EA YR KVIDQLSAGKHIQS IVAR GVGGSI GGGA GDDAEP LS: DVAHG I LD KA YR KVIDQL S R RY LOTLM AK GL GGTP GG GA DDDSEPLS. - HA DGI FS KA YR KLIG QLSA RNYLRSLMAK RVGGA. SS GL GDEAEPLS.

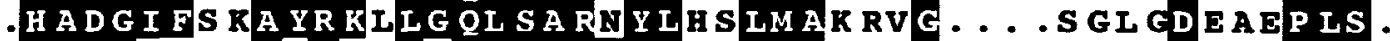
. H A DGL LD RAIRD I IVQL SA RK Y LHSLMAVRVGG . GS SE EDESEPIS. . H A DGI LD RAIRDILVQL SARK YLHSITAVRVGE . . EE EDEEDSEPIS. . HA DGMFN KA YRKALG QL SARK YLETLMAKRVGG . . GS MI EDDNEPIS. . H A D GMFN KA YR KAFG QL SARK Y LETIMAKRVGG. . GSTTEDDNEP LS. . H A D GMFN KA YR KALG QL SARK Y LESLMAK RVGG . . GS TMEDDTEP LS. IFA DG T FN KA YR KVLGOT, SARK YLHS VMAK RVEG . V VS SM EDDSEPTS. - IA DAI FT NSYR KVLG QL SARKILQD IMNR QQGE. . . R NQ . E QGAKVRI . YADAI FT NSYR KILG QL SARKILQD IMNRQQGE . . R NQ . EQGAKVRI . IA DAI FTSSYR KVLG QL SARKIL DD IMSRQQGE . . R NQ . E QGPRVRI - IA DAI FT NS YR KVIG QL SARKILQD IMSRQQGE . . R NQ E EGAR VRI - IA DAI FT NSYRKVIG QL SARK ILQD IMSR QQGE . . S NQ . E RGARARI . HA DAI FTS S YRR ILG QLYARKILHE IMNR QQ GE . . R NQ E E RSRFN . . HVDAI FT TNYRKLISQLYARKYIQD IMNKQ . GE . . R IQ . EQRARLS. 
Fig. 1. A) Schematic representation of the fish PACAP gene and preproPACAP. Similar to mammals, the fish PACAP gene is composed of five exons and four introns. The structure of PACAP preprohormone is shown below the diagram of PACAP gene. The putative monobasic and dibasic cleavage sites in the preproPACAP are indicated by the vertical bars. The single-letter code is used for the amino acid residues signifying the cleavage sites. Legend: $R$, arginine; $K$, lysine; and $G$, glycine. As a result of the cleavage of preproPACAP, mature peptides of fish GHRH, PACA27, and PACAP38 are expected to be generated. B) Alignment of the amino acid sequence of fish PACAP38 with that of other vertebrates. C) Alignment of the amino acid sequence of fish GHRH with that of GHRH and PRP from other vertebrates. The comparison of sequences was based on Waterman algorithm (CLUSTAL 4) using a window width of 20 amino acids. The regions of conserved amino acid residues are marked by black boxes. The symbol $\bullet$ indicates the gap introduced into the sequence to allow for the maximal degree of sequence homology in the alignment.

immunostaining has also been reported in chromaffin cells of the posterior cardinal vein of rainbow trout, dogfish, and hagfish (Reid et al. 1995). However, its functional role in regulating catecholamine release in these fish species remains to be determined. Besides the peripheral tissues, PACAP has also been detected in the CNS of fish. In recent years, PACAP has been purified from the brain of stargazer (Matsuda et al. 1997b) and European eel (Montero et al. 1998). Similar to mammals, the predominant form of PACAP found in the brain of these teleost species is PACAP38. In European eel, most of the PACAP perikarya are located in the preoptic area of the hypothalamus (e.g., nucleus preopticus) with fibers ramified to various parts of the brain (Montero et al. 1998). In elasmobranch, like the stingray, cell bodies and nerve fibers with PACAP immunoreactivity are also identified in similar areas of the hypothalamus (Matsuda et al. 1998a). The presence of a PACAP neuronal system within the fish CNS is consistent with the role of PACAP as a neurotransmitter (Masuo et al. 1993) and neurotrophic factor (Lindholm et al. 1998). In the goldfish (Wong et al. 1998a), European eel (Montero et al. 1998), stargazer (Matsuda et al. 1997a), stingray (Matsuda et al. 1998a), and more recently in grass carp (Leung et al. 1998), nerve fibers with PACAP immunoreactivity are located in different parts of the pituitary. In the stargazer, PACAP nerve fibers can be identified in the anterior neurohypophysis and rostral pars distalis (Matsuda et al. $1997 a$ ). In European eel, a dense network of PACAP nerve fibers are found mostly in the pars distalis (Montero et al. 1998). In the goldfish, PACAP fibers are present in the pars distalis and neurointermediate lobe (Fig. 2). Goldfish pituitary cells with PACAP immunoreactivity are also located in the posterior pituitary, especially in areas surrounding some blood vessels (Wong et al. 1998a). These findings suggest that PACAP may serve multiple functions at the pituitary level in fish. First, it may be synthesized in the hypothalamus and delivered to the pituitary to serve as a hypophysiotropic factor. The distribution of PACAP cell bodies and fibers in the hypothalamo-pituitary axis of representative fish species is consistent with the general observation that the anterior pituitary of teleosts is under the direct innervation of hypothalamus (Kah et al. 1993). Second, PACAP may be released from nerve terminals in the posterior pituitary to modulate neurolobe hormone secretion. Alternatively, it may be released directly into systemic circulation, and in this case PACAP itself may serve as a neurohypophysial hormone. The demonstration of pituitary cells in fish with PACAP immunoreactivity also suggests that PACAP may be produced locally within the pituitary and function as an autocrine or paracrine factor. This hy-
Fig. 2. Immunostaining of PACAP nerve fibers in the rostral (A and $B$ ) and proximal pars distalis (C and D) of the goldfish pituitary. Immunoreactivity of PACAP (indicated by arrows) was identified in the nerve tracks located in the rostral pars distalis (RPD). In the proximal pars distalis (PPD), PACAP immunostaining exhibited a diffused pattern of distribution and was found mainly in nerve fibers of a smaller size. Panels on the left are pituitary sections $(\times 400)$ under phase contrast microscopy ( $\mathrm{A}$ and $\mathrm{C}$ ), the corresponding bright field pictures are presented on the right ( $B$ and $D$ ). Comparing the pictures under phase contrast and bright field illumination yields no evidence for the presence of PACAP immunoreactivity in pituitary cells within the pars distalis of the goldfish. The distribution pattern of PACAP nerve fibers in the neurointermediate lobe is similar to that of the proximal pars distalis (not shown).

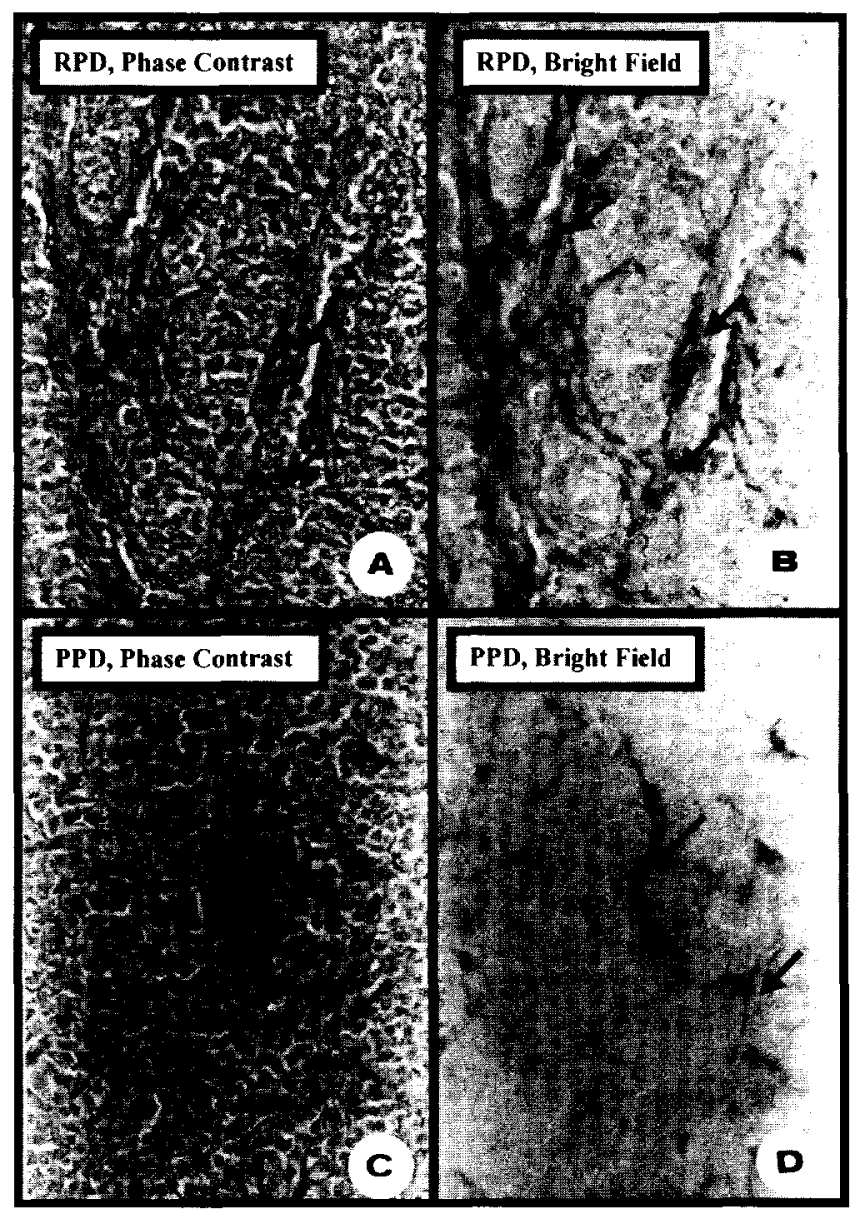


Table 1. Expression of mRNA transcripts for PACAP(GHRH), VIP(PHI), PAC1, VPAC1, PHI (VPAC2), and GHRH receptors in different tissues of the goldfish. ${ }^{a}$

\begin{tabular}{|c|c|c|c|c|c|c|}
\hline Tissue & PACAP (GHRH) & VIP (PHI) & $\mathrm{PACl}$ & GHRH & VPACl & PHI (VPAC2) \\
\hline Brain & ++++ & +++ & +++ & ++++ & +++ & ++ \\
\hline Olfactory bulbs & ++++ & - & ++ & ND & ++ & ++ \\
\hline Telencephalon & ++++ & - & +++ & ND & +++ & +++ \\
\hline Hypothalamus & ++++ & - & +++ & ND & +++ & +++ \\
\hline Optic tectum \& thalamus & ++++ & - & +++ & ND & +++ & ++ \\
\hline Cerebellum & ++++ & - & ++ & ND & ++ & ++ \\
\hline Medulla oblongata & ++++ & +++ & +++ & ND & ++ & ++ \\
\hline Spinal Cord & ++++ & +++ & ++ & ND & ++ & + \\
\hline Pituitary & +++ & - & + & ++ & + & ++++ \\
\hline Testes & ++++ & + & - & +++ & - & ++ \\
\hline Ovary & + & - & - & & ++++ & - \\
\hline Gill & + & ND & - & ++ & + & ND \\
\hline Kidney & +++ & ND & - & - & +++ & ND \\
\hline Intestine & ++++ & ++++ & - & + & + & ++++ \\
\hline Liver & + & - & - & + & - & +++ \\
\hline Heart & + & ++ & +++ & ++ & + & + \\
\hline Gall bladder & ND & +++ & - & - & +++ & ++++ \\
\hline Spleen & ND & ND & - & ++ & + & ND \\
\hline Muscle & ND & ND & - & + & + & ND \\
\hline
\end{tabular}

"Expression of transcripts was tested by RT-PCR using primers specific for mRNAs of goldfish PACAP(GHRH), VIP(PHI), and their respective receptors.,,.++++++++++ , and - represent a very high level, high level, medium level, low level, and no expression of target mRNA, respectively. For those tissues in which RT-PCR was not performed, ND indicates that expression of target mRNA was not determined.

pothesis is supported by our recent findings that PACAP mRNA is expressed in the goldfish pituitary (Leung et al. $1999 a$ ). It must be stressed that in the fish model these putative functions of PACAP at the pituitary level are not mutually exclusive. In our recent studies using RT-PCR, we have shown that PACAP expression in the goldfish appears to be ubiquitous. PACAP mRNA can be detected in different parts of the brain as well as in other tissues, including the pituitary, spinal cord, kidney, gut, liver, heart, and gonads (Table 1). Such a wide range of tissue distribution of PACAP in goldfish is comparable to the situation in mammals and may indicate that this peptide is involved in a wide array of biological functions in fish.

\section{PACAP receptors and their expression in the brain- pituitary axis: The goldfish model}

The biological actions of PACAP are mediated through three different types of PACAP receptors, named PAC1, VPAC 1, and VPAC2 (Harmar et al. 1998). All of them are G protein-coupled receptors with a classical structure of seven transmembrane domains (TMD) and can be distinguished pharmacologically by their relative affinities for PACAP, VIP, and the lizard venom helodermin (for reviews, see Rawlings 1994; Arimura and Shioda 1995). PACl receptors exhibit a high affinity binding for PACAP but not for VIP. In mammals, isoforms of PACl receptors as a result of alternative splicing of hip/hop1/hop2 inserts in the third intracellular loop have been reported (Spengler et al. 1993); these receptors are differentially coupled to adenylate cyclase and phospholipase C (Journot et al. 1995). Two additional variants of $\mathrm{PACl}$ receptors, one with $\mathrm{N}$-terminal truncation (Pantaloni et al. 1996) and the other with structural modifications in TMD4 (Chatterjee et al. 1996), have also been cloned. In contrast with other PAC1 receptors, the receptor variant with a modified TMD4 does not stimulate cAMP or IP3 production, but rather induces $\mathrm{Ca}^{2+}$ influx through activation of L-type $\mathrm{Ca}^{2+}$ channels. VPACl and VPAC2 receptors, unlike $\mathrm{PACl}$ receptors, can bind both PACAP and VIP with high affinity, and these receptors are also referred to as the VIP receptors in some studies. These two subtypes of VPAC receptors can be differentiated by their binding affinity for helodermin. In this case, VPAC1 receptors represent the classical VIP receptors with low affinity for helodermin (Couvineau et al. 1994), whereas VPAC2 receptors are the helodermin-perferring VIP binding site reported in some cell lines, e.g., SUP-T1 lymphoblasts (Svoboda et al. 1994) and some insulin-secreting cell lines (Inagaki et al. 1994). In general, VPAC1 and VPAC2 receptors do not activate IP turnover and are functionally coupled to the cAMP-dependent pathway (Rawlings and Hezareh 1996).

Recently, PACl receptors have been cloned in the zebrafish and found to share $\sim 70 \%$ amino acid sequence homology with the human counterpart (Wei et al. 1998). Two isoforms of zebrafish PACl receptors, one with and one without the hop2 insert, have been expressed in Chinese hamster lung (CHL) cells and shown to bind PACAP but not VIP with high affinity. Since tissue distribution and functional studies of these receptors have not been conducted in zebrafish, the biological functions of PACAP in this fish species are unknown. In the goldfish, a PAC1 receptor cDNA has been cloned from a pituitary cDNA library (Wong et al. $1998 a$ ). The amino acid sequence of this PACl receptor is $85.7 \%$ and $85.1 \%$ homologous to that of the rat (Pisegna and Wank 1993) and human PAC1 receptors (Ogi et al. 1993), respectively. Expression of this receptor cDNA in COS-7 cells reveals that goldfish $\mathrm{PAC} 1$ receptors are functionally coupled to cAMP synthesis. CAMP production in these 
COS-7 cells can be stimulated specifically with PACAP38 and PACAP27, but not by VIP, GHRH, secretin, glucagon, or PHM. Furthermore, the expression of these PACl receptors in the goldfish is tissue-specific. Transcripts of this receptor can be identified only in the pituitary, brain, and heart, but not in other tissues (Table 1). Two isoforms of VPACl receptors have also been cloned in the goldfish (Chow et al. 1997). These goldfish receptors share only 62$68 \%$ sequence homology with human VPAC1 receptors (Couvineau et al. 1994). In contrast to the restricted distribution of $\mathrm{PACl}$ receptors, expression of VPACl receptors in goldfish can be detected in a variety of tissues, including the brain, pituitary, kidney, gut, spleen, gill, heart, muscle, and gall bladder (Table 1). Functional expression of goldfish VPAC1 receptors in COS-7 cells has shown that these receptors are also coupled to the cAMP-dependent pathway (Chow et al. 1997) and exhibit binding affinity for both PACAP38 and VIP (Chow 1997). Interestingly, the efficacy of VIP to stimulate cAMP synthesis via activation of these VPACl receptors is at least 100 -fold higher than that of PACAP38, suggesting that these fish VPACl receptors are more sensitive to VIP stimulation. These results are at variance with the properties of VPAC1 receptors reported in mammals, in which PACAP and VIP always induce biological responses with similar potency and efficacy.

Both PACAP (Leung et al. 1999b) and VIP (Tse et al. 1997) have been cloned from a cDNA library prepared from the brain and pituitary of the goldfish. In the preprohormone of goldfish VIP, a highly conserved peptide histidine isoleucine (PHI) has been identified $5^{\prime}$ upstream of the coding sequence of VIP. The deduced amino acid sequence of this goldfish VIP from the brain-pituitary axis is also identical with the sequence of a VIP preparation purified from the intestine of the same species (Uesaka et al. 1995). Unlike the ubiquitous expression pattern of PACAP, mRNA messages of VIP are expressed in the goldfish in a tissue-specific manner (Table 1). VIP transcripts can be detected at high levels mainly in the brain and intestine, and to a less extent in the heart and testes, but not in the pituitary, ovary, and liver. It is also noted that VIP expression within the CNS is restricted to the brain stem, including the medulla oblongata and spinal cord; it is not found in other brain areas. This is quite different from the expression pattern of PACAP mRNA, which is present at high levels throughout the brain-pituitary axis of the goldfish. In contrast to a high level of PACAP expression in the hypothalamus, VIP mRNA transcripts are not detected in this brain area, suggesting that this peptide may not serve as a hypophysioptropic factor in fish. The absence of VIP expression in the goldfish pituitary is also different than that in mammals in which VIP is produced locally in the pituitary to serve as an autocrine and paracrine factor to mediate TRH-stimulated PRL release (Balsa et al. 1996). In the goldfish, GHRH analogs, such as human (Peter et al. 1984) and carp GHRH (Vaughan et al. 1993), are known to stimulate $\mathrm{GH}$ release in vivo and in vitro. In addition, the perikarya with GHRH immunoreactivity are located in the preoptic region of the hypothalamus with nerve fibers extending into the anterior pituitary (Rao et al. 1996). These findings are consistent with the demonstration that fulllength PACAP mRNA transcripts with a GHRH-coding region can be detected in the goldfish hypothalamus (Table 1).
Fig. 3. Additivity of the GH-releasing actions of salmon GnRH (sGnRH) and zebrafish PACAP38 (ZF.PACAP38) in perifused goldfish pituitary cells. A) A 5 min pulse of ZF.PACAP38 $(100 \mathrm{nM})$ was given alone or applied during the $2 \mathrm{~h}$ continuous perifusion of sGnRH $(100 \mathrm{nM})$. In this study, a $2 \mathrm{~h}$ continuous perifusion of $\mathrm{sGnRH}(100 \mathrm{nM})$ was used as the control treatment. B) In the reciprocal experiments, a 5 min pulse of sGnRH $(100 \mathrm{nM})$ was given with or without the $2 \mathrm{~h}$ continuous perifusion of ZF.PACAP38 (100 nM). In this case, a $2 \mathrm{~h}$ perifusion of ZF.PACAP38 (100 nM) was used as the control. GH data presented (mean \pm SEM) are pooled results from at least four separate perifusion experiments $(n=4-6)$. In our previous in vitro studies, sGnRH and ZF.PACAP38 given at a $100 \mathrm{nM}$ dose are known to trigger their respective maximal GH responses in perifused goldfish pituitary cells.

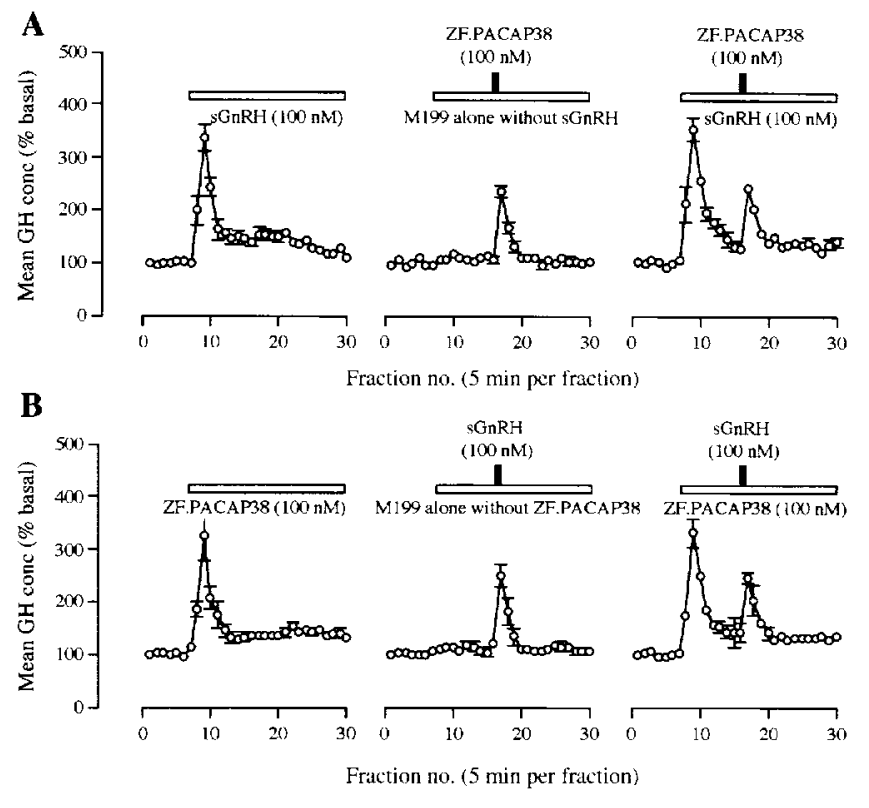

In the same animal model, the receptor for GHRH has been cloned and its expression in the pituitary has been recently confirmed (Chan et al. 1998). Besides the sensitivity to stimulation by carp GHRH, these goldfish GHRH receptors can also be activated by nano-molar doses of human GHRH and PACAP38. Other structurally related peptides, such as VIP, PHM, PTH, GIP, and secretin, are far less effective in this regard. Since the anterior pituitary of teleost fish is under the direct innervation of the hypothalamus (Kah et al. 1993), a high level of PACAP is expected to be present in the vicinity of nerve terminals of PACAP and (or) GHRH neurons located in the proximal pars distalis. Therefore, we do not exclude the possibility that PACAP may serve as an endogenous ligand to activate GHRH receptors in the goldfish pituitary. More recently, a novel G-protein coupled receptor with structural similarity with mammalian VPAC2 receptors has been cloned in the goldfish (Tse 1999). Functional expression of this receptor cDNA in CHO cells reveals that these goldfish receptors can be activated selectively by goldfish PHI or by the mammalian equivalent peptide histidine methionine (PHM). Helodermin, a selective ligand for mammalian VPAC2 receptors, is also effective in activating these newly cloned goldfish receptors, but surprisingly, these receptors are not sensitive to stimulation with PACAP38 or 
Fig. 4. Effects of ovine PACAP38 on basal GH release from perifused goldfish pituitary cells. Increasing doses $(0.1 \mathrm{nM}-1 \mu \mathrm{M} ; \mathrm{A})$ or decreasing doses $(1 \mu \mathrm{M}-0.1 \mathrm{nM} ; \mathrm{B})$ of ovine PACAP3 8 were administered as five consecutive 5 min pulses at $1 \mathrm{~h}$ intervals as indicated by the vertical bars. GH data presented (mean \pm SEM) are pooled results from four separate perifusion experiments $(n=4)$.

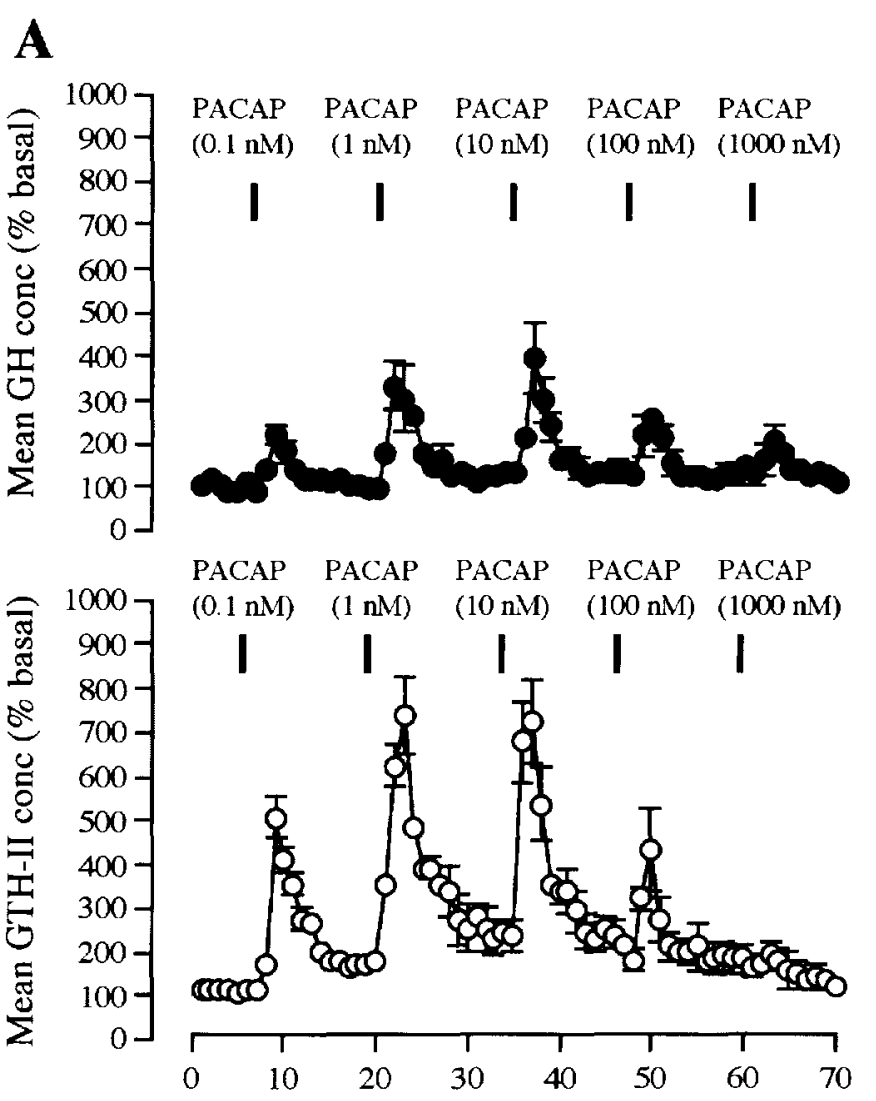

Fraction number ( 5 min per fraction)

\section{B}

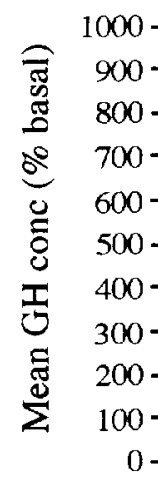

$\begin{array}{lllll}\text { PACAP } & \text { PACAP } & \text { PACAP } & \text { PACAP } & \text { PACAP } \\ (1000 \mathrm{nM}) & (100 \mathrm{nM}) & (10 \mathrm{nM}) & (1 \mathrm{nM}) & (0.1 \mathrm{nM})\end{array}$

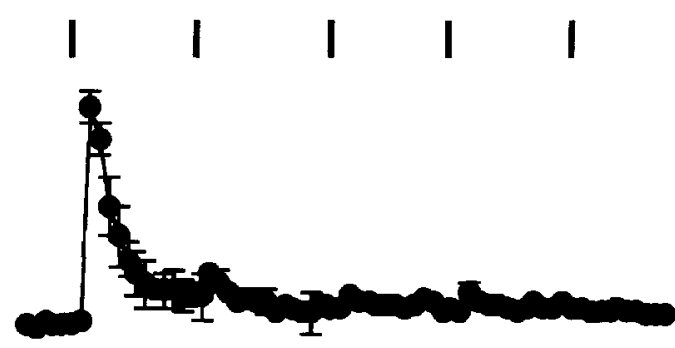

PACAP PACAP PACAP PACAP PACAP $(1000 \mathrm{nM}) \quad(100 \mathrm{nM}) \quad(10 \mathrm{nM}) \quad(1 \mathrm{nM}) \quad(0.1 \mathrm{nM})$

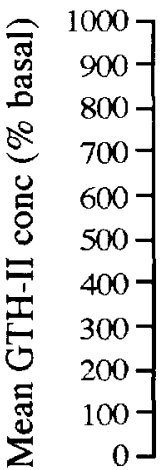
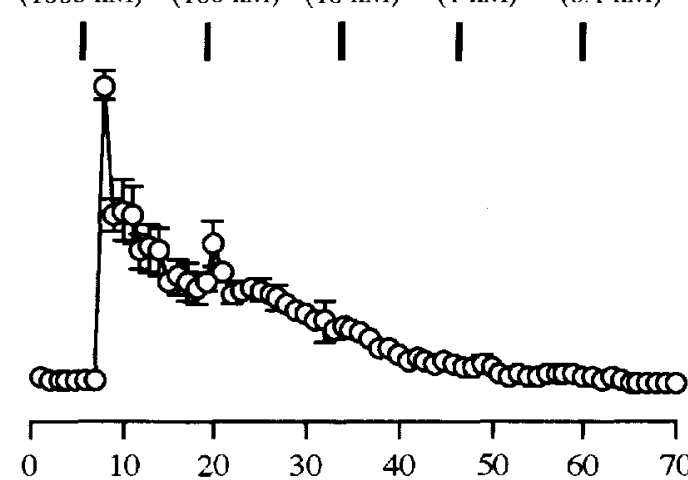

Fraction number ( 5 min per fraction)

Table 2. Effects of ip injection of goldfish PACAP38a and PACAP38b on plasma GH and GTH-II concentrations (mean \pm $\mathrm{SEM}$ ) in the goldfish.

\begin{tabular}{|c|c|c|c|c|}
\hline \multirow[b]{2}{*}{ Drug treatment } & \multicolumn{2}{|c|}{$\begin{array}{l}\text { Plasma hormone level }\left(\mathrm{ng} \cdot \mathrm{mL}^{-1}\right) \text { at: } \\
2 \mathrm{~h} \text { postinjection }\end{array}$} & \multicolumn{2}{|c|}{$4 \mathrm{~h}$ postinjection } \\
\hline & $\mathrm{GH}$ & GTH & $\mathrm{GH}$ & GTH \\
\hline \multicolumn{5}{|c|}{ Goldfish undergoing sexual regression ${ }^{a}$} \\
\hline Saline $(0.7 \%)$ & $\begin{array}{l}6.2 \pm 1.0 \\
(n=18)\end{array}$ & $\begin{array}{l}7.7 \pm 0.4 \\
(n=18)\end{array}$ & $\begin{array}{l}6.5 \pm 0.9 \\
(n=18)\end{array}$ & $\begin{array}{l}8.1 \pm 0.6 \\
(n=18)\end{array}$ \\
\hline $\begin{array}{l}\text { PACAP38a } \\
\left(0.1 \mu \mathrm{g} \cdot \mathrm{g}^{-1} \mathrm{BW}, \text { ip }\right)\end{array}$ & $\begin{array}{l}13.7 \pm 1.3^{*} \\
(n=19)\end{array}$ & $\begin{array}{l}12.2 \pm 1.2^{*} \\
(n=20)\end{array}$ & $\begin{array}{l}10.6 \pm 1.0^{*} \\
(n=19)\end{array}$ & $\begin{array}{l}11.7 \pm 0.9 * \\
(n=20)\end{array}$ \\
\hline \multicolumn{5}{|c|}{ Goldfish undergoing sexual recrudescence ${ }^{b}$} \\
\hline Saline $(0.7 \%)$ & $\begin{array}{l}24.5 \pm 2.0 \\
(n=19)\end{array}$ & $\begin{array}{l}14.4 \pm 0.6 \\
(n=18)\end{array}$ & $\begin{array}{l}23.4 \pm 2.1 \\
(n=19)\end{array}$ & $\begin{array}{l}15.3 \pm 1.4 \\
(n=18)\end{array}$ \\
\hline $\begin{array}{l}\text { PACAP38b } \\
\left(0.1 \mu \mathrm{g} \cdot \mathrm{g}^{-1} \mathrm{BW}, \mathrm{ip}\right)\end{array}$ & $\begin{array}{l}41.3 \pm 3.1 * \\
(n=20)\end{array}$ & $\begin{array}{l}19.5 \pm 0.6^{*} \\
(n=17)\end{array}$ & $\begin{array}{l}30.3 \pm 2.6^{*} \\
(n=20)\end{array}$ & $\begin{array}{l}20.9 \pm 0.7^{*} \\
(n=17)\end{array}$ \\
\hline
\end{tabular}

VIP. In addition, these PHI (VPAC2) receptors are expressed at high levels in the pituitary, hypothalamus, optic tectum, and thalamus of the goldfish (Table 1). The functional role of these receptors in the brain-pituitary axis in fish is unknown and remains to be investigated.
$P A C A P$ regulation of $G H$ and $G T H-I I$ release in fish: Receptor specificity and signal transduction

PACAP regulation of pituitary hormone release in fish was first reported by Sherwood's group (Parker et al. 1997). In this pioneer study, salmon PACAP38 was shown to ele- 
Fig. 5. A working model on signal transduction mechanisms mediating PACAP-stimulated GH release from goldfish somatotrophs. In this model, PACAP binding with membrane PAC 1 receptors activates two post-receptor signaling pathways, namely the AC-cAMPPKA and PLC-IP3-PKC pathways. PKA and PKC can stimulate extracellular $\mathrm{Ca}^{2+}$ influx either directly through the opening of VSCC or indirectly via activation of TTX-sensitive $\mathrm{Na}^{+}$channels. IP3 produced as a result of PLC activation may also trigger Ca ${ }^{2+}$ release from intracellular $\mathrm{Ca}^{2+}$ stores. The combined actions of extracellular $\mathrm{Ca}^{2+}$ influx via VSCC and mobilization of intracellular $\mathrm{Ca}^{2+}$ stores can activate CAM kinase II in a $\mathrm{Ca}^{2+}$ - and calmodulin-dependent manner to trigger $\mathrm{GH}$ exocytosis.

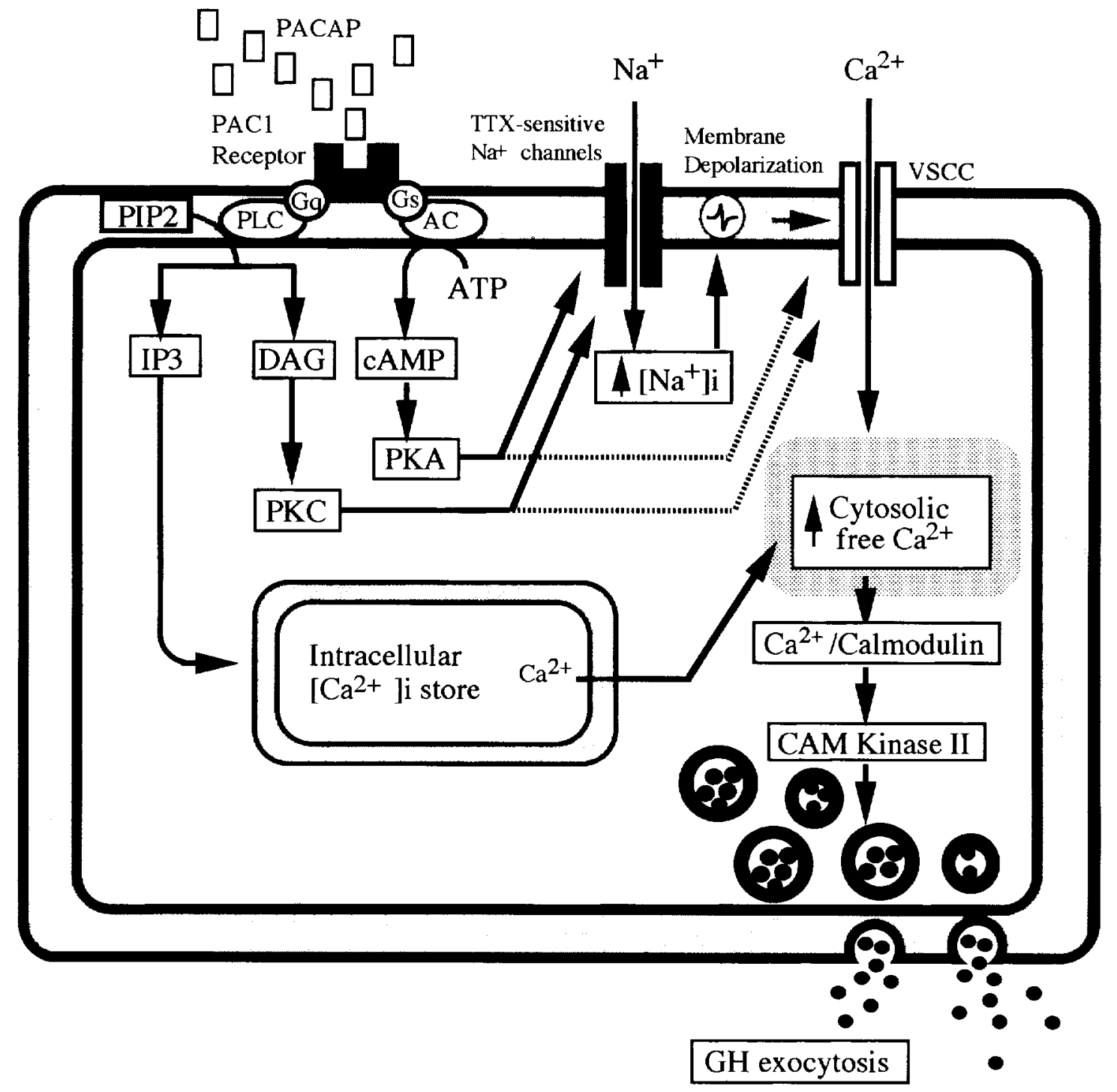

vate basal $\mathrm{GH}$ release from trout pituitary cells in a dosedependent manner. Using mammalian PACAP analogs, similar GH-releasing effects have been demonstrated in pituitary cell cultures of two other teleost species, including the goldfish (Wong et al. 1998a) and European eel (Montero et al. 1998). In the goldfish, a well-known representative of the Cyprinids, two forms of PACAP38, PACAP38a and $38 \mathbf{b}$, have been cloned (Leung et al. 1999b; Fig. 1). These PACAP isoforms are both effective in stimulating $\mathrm{GH}$ release from goldfish pituitary cells in the nanomolar dose range (Leung et al. $1999 a$ ). In contrast with mammals, in which PACAP is only a weak stimulator of GH release, the magnitude of $\mathrm{GH}$ responses induced by goldfish PACAPs is similar, if not higher, than that of other known GH-releasing factors reported in the goldfish (e.g., GnRH, GHRH, dopamine, and neuropeptide $Y$ ). These results suggest that
PACAP may serve as a potent $\mathrm{GH}$ secretagogue, at least in the Cyprinids. This hypothesis is consistent with our recent findings that ovine PACAP38 is highly effective in stimulating GH release in Chinese grass carp (Leung et al. 1998) and common carp (unpublished results, H.R. Lin and A.O.L. Wong). In the goldfish, GnRH is known to be an important GH-releasing factor, especially during the reproductive season (Marchant et al. 1989). In our in vitro perifusion studies, the efficacy of ovine PACAP38 in inducing GH release was highest when using pituitary cells prepared from goldfish during sexual maturation (Leung et al. 1997), and the GHreleasing action of zebrafish PACAP38 is also additive to that of salmon GnRH (Fig. 3). Although PACAP38 has been shown to potentiate GnRH-stimulated LH release in rat pituitary cells (McArdle and Counis 1996), a similar potentiating effect on $\mathrm{GnRH}$-stimulated $\mathrm{GH}$ release is not evident in 
the fish model. Based on our previous studies, we have demonstrated that basal $\mathrm{GH}$ release in the goldfish is under the negative regulation of somatostatin (Wong et al. 1993), norepinephrine (Lee et al. 1999), and serotonin (Wong et al. $1998 b$ ). In our recent studies, these GH-release inhibitors are all effective in suppressing the $\mathrm{GH}$ responses triggered by PACAP analogs in goldfish pituitary cells (Leung 1999), suggesting that PACAP can interact with these GH regulators at the pituitary level to modulate $\mathrm{GH}$ secretion. It was also noted that goldfish PACAP-stimulated $\mathrm{GH}$ release in vitro can be inhibited by simultaneous treatment with PACAP antagonists. In the same animal model, VIP does not alter basal GH secretion and VIP antagonists are not effective in blocking the GH-releasing action of PACAP (Wong et al. 1998a). Similarly, in European eel, VIP has no effect (at submicromolar doses) in stimulating GH release from cultured eel pituitary cells (Montero et al. 1998). These results indicate that the GH-releasing action of PACAP in fish is mediated via pituitary PACl receptors, but not VPAC receptors. Although both PAC1 and VPAC1 receptor mRNAs are expressed in the goldfish pituitary (Table 1), the general lack of VIP responses in terms of $\mathrm{GH}$ release argues against the involvement of VPAC receptors in PACAP's action. These observations in fish are also at variance with the studies in rat somatotroph-derived cell lines (e.g., GH3 cells), in which the GH-releasing action of PACAP is mediated via VPAC2 receptors (Murakami et al. 1995). As a matter of fact, PACl receptors are not expressed in these cell lines at significant levels (Rawlings et al. 1995).

In the goldfish, PACAP nerve fibers have been identified in the anterior pituitary (Fig. 2) and some of them overlap with the distribution of somatotrophs in the proximal pars distalis (Wong et al. 1998a). Given that goldfish gonadotrophs and somatotrophs are closely intermingled with each other in the anterior pituitary (Ge and Peter 1994), PACAP nerve terminals are also expected to be present, in close proximity with gonadotrophs. Therefore, we speculate that PACAP may also play a role in regulating GTH release in the goldfish. In our preliminary studies, increasing doses of ovine PACAP38 $(0.1 \mathrm{nM}-1 \mu \mathrm{M}$, given as $5 \mathrm{~min}$ consecutive pulses) were effective in inducing both $\mathrm{GH}$ and GTH-II release from goldfish pituitary cells (Fig. 4A). In these perifusion studies, the doseresponse curves of PACAP38-stimulated GH and GTH-II release were found to be bell-shaped. A similar bell-shaped curve for PACAP38-stimulated $\mathrm{GH}$ release has been previously reported in perifused rat pituitary cells (Miyata et al. 1989). This bell-shaped dose-response curve in the rat model has been attributed to receptor desensitization as a result of repeated stimulation by increasing doses of ovine PACAP38 (Wei et al. 1993). A similar desensitization mechanism seems to be present in the goldfish model. This concept is supported by our parallel experiments with goldfish pituitary cells exposed to decreasing doses of ovine PACAP38 (Fig. 4B). In this case, significant increases of GH and GTH-II release were only observed after the first pulse of PACAP38 given at $1 \mu \mathrm{M}$. After that, little or no GH or GTH-II responses could be detected in subsequent PACAP38 pulses given at lower doses. At present, the mechanism involved in this desensitization phenomenon is still unknown, although the possibility of downregulation of PACAP receptor number and (or) uncoupling of the associated signal transduction pathways cannot
Fig. 6. Effects of PACAP38 on steady-state GH mRNA levels in fish pituitary cells. A) Time-course of ovine PACAP38 on GH mRNA levels in goldfish pituitary cells. In this experiment, pituitary cells were cultured overnight in the presence of $1 \%$ horse serum. On the following day, medium with horse serum was discarded and ovine PACAP38 $(1 \mu \mathrm{M})$ was introduced. In the control group, pituitary cells were treated with normal culture medium M199 alone. After that, pituitary cells were harvested for total RNA extraction and subsequent slot-blot analysis at the times as indicated. The small inset summarized the data on foldincrease of GH mRNA levels after PACAP treatment with respect to that of the time-matched control. B) Dose-dependence of PACAP38 on GH mRNA levels in grass carp pituitary cells. Grass carp pituitary cells were cultured in the presence of increasing doses of ovine PACAP38 $(0.1-10 \mu \mathrm{M})$. The duration of drug treatment was routinely fixed at $48 \mathrm{~h}$ in these experiments. C) Effects of protein kinase A inhibition on PACAP38 stimulation of GH mRNA levels in grass carp pituitary cells. The protein kinase A inhibitor $\mathrm{H} 89(30 \mu \mathrm{M})$ was given to pituitary cell cultures for $48 \mathrm{~h}$, either alone or together with ovine PACAP38 $(0.5 \mu \mathrm{M})$. Treatment with PACAP38 $(0.5 \mu \mathrm{M})$ alone was used as the positive control in this study. To adjust for the variability of sample loading in slot-blot analysis, $\beta$ actin mRNA was used as the internal control. The steady-state levels of GH mRNA in fish pituitary cells are expressed as the ratio of $\mathrm{GH}$ mRNA over $\beta$ actin mRNA.
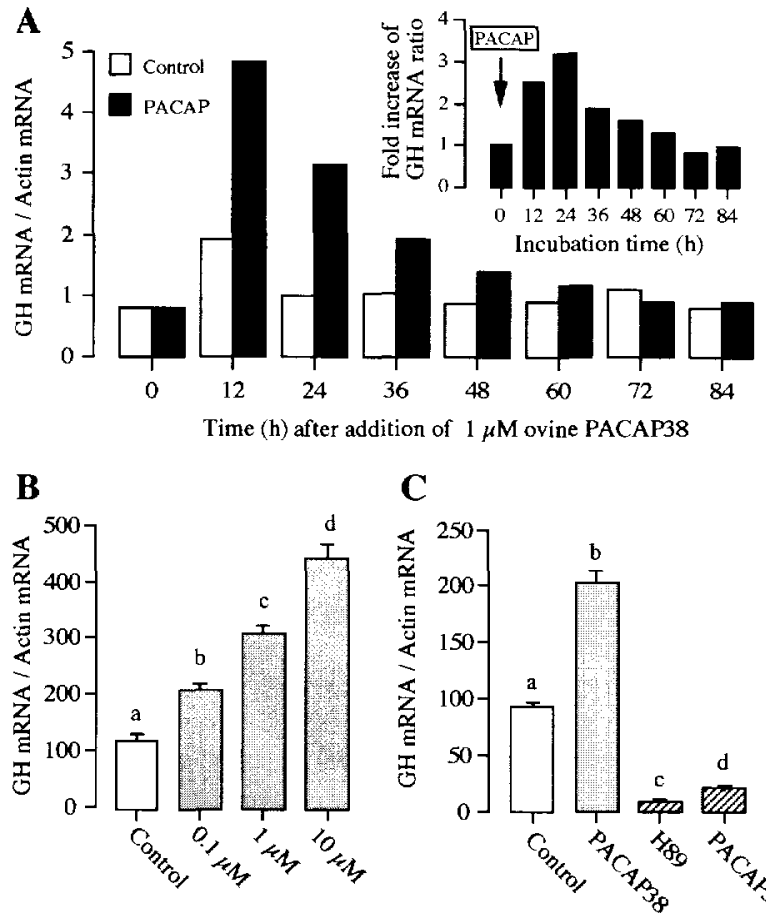

C

Ovine PACAP38 dose

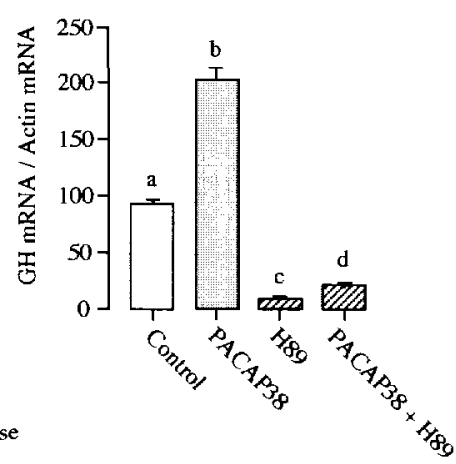

be excluded. In our recent in vivo studies, intraperitoneal injection of goldfish PACAP38a and $38 \mathrm{~b}$ were effective in elevating plasma GH and GTH-II levels in goldfish at different reproductive stages (Table 2). In addition, both basal $\mathrm{GH}$ release as well as the $\mathrm{GH}$-releasing actions of goldfish PACAP38a and $38 \mathrm{~b}$ could be significantly inhibited in vivo using a high dose of the PACAP antagonist PACAP6-38 (Leung et al. 1999a). These results indicate that PACAP 
functions as a novel hypophysiotropic factor in fish, inducing $\mathrm{GH}$ and GTH-II release at the pituitary level, and that these stimulatory actions are highly susceptible to receptor desensitization. At present, the receptor subtype(s) mediating PACAP-stimulated GTH-II release has not been fully elucidated in the goldfish. Nevertheless, the possible involvement of VPAC receptors has been implicated, as submicromolar doses of VIP have been shown to stimulate GTH-II release from goldfish pituitary cells under static incubation conditions (unpublished results, C. Peng and J.P. Chang). In our preliminary studies, however, a significant increase in basal GTH-II release from perifused goldfish pituitary cells could only be demonstrated at micromolar doses of VIP (unpublished results, L.Y. Tse and A.O.L. Wong). We speculate that the GTH response observed in our perifusion studies might have been the result of crossreactivity of high doses of VIP with PAC1 receptors. Since the reproductive stages of fish used in these experiments were not recorded, we do not exclude the possibility that the observed discrepancy in sensitivity to VIP stimulation may have resulted from differential expression of VPAC receptors at different times of the reproductive cycle. Alternatively, the discrepancy in sensitivity may be due to the involvement of an autocrine or paracrine factor(s) that had accumulated to reach significant levels after prolonged incubation of goldfish pituitary cells. A similar accumulation of secreted products is rather unlikely in the flow-through system used in our perifusion studies.

In mammals, $\mathrm{PAC} 1$ receptors are functionally coupled to adenylate cyclase (AC) and phospholipid C (PLC; for review, see Rawlings and Hezareh 1996). Increases in cAMP (Spengler et al. 1993) and IP3 production (Schomerus et al. 1994), mobilization of intracellular $\mathrm{Ca}^{2+}$ stores (Tanaka et al. 1998), and extracellular $\mathrm{Ca}^{2+}$ entry through voltage-sensitive $\mathrm{Ca}^{2+}$ channels (VSCC; Chatterjee et al. 1996) have been reported in the post-receptor signaling mechanisms after PAC1 receptor activation. In the goldfish, $\mathrm{PACl}$ receptors are involved in PACAP-stimulated GH release at the pituitary level (Wong et al. 1998a). Mammalian PACAP analogs and goldfish PACAPs are effective in stimulating cAMP synthesis (Leung et al. 1997), intracellular $\mathrm{Ca}^{2+}$ levels (Leung et al. $1999 \mathrm{~b}$ ), and inositol phosphate production (Wong et al. $1996 b$ ) in goldfish pituitary cells. Furthermore, the GHreleasing action of PACAP can be attenuated by the $\mathrm{AC}$ inhibitor MDL12330A and the protein kinase A (PKA) inhibitor H89, suggesting that the AC-cAMP-PKA pathway is a part of the signaling mechanisms mediating $\mathrm{GH}$ release after PACl receptor activation (Leung 1999). These results are consistent with our previous findings that $\mathrm{GH}$ exocytosis in goldfish pituitary cells can be induced by the activation of AC using forskolin, or an increase in functional levels of cAMP using 8Br.cAMP (Wong et al. 1994a). PACAPstimulated $\mathrm{GH}$ release from goldfish pituitary cells can also be suppressed by the PLC inhibitor UK73122, protein kinase $\mathrm{C}$ (PKC) desensitization, and PKC inhibitors like calphostin $C$ and cherythrine (Leung 1999). These observations indicate that the goldfish PAC1 receptors are functionally coupled to the PLC-IP3-PKC pathway. In our recent in vitro studies, a $\mathrm{Ca}^{2+}$-dependent component was also identified in PACAP-stimulated $\mathrm{GH}$ release in the goldfish. In this case, removal of extracellular $\mathrm{Ca}^{2+}$, blockade of VSCC using nifedipine and nicardipine (Leung et al. 1997), and inhibition of $\mathrm{Ca}^{2+}$-calmodulin-dependent protein kinase II (CAM kinase II) using KN62 and KN93 (Leung 1999) were all effective in blocking the GH-releasing action of PACAP. In the goldfish, we have previously shown that PKA and PKC activation can induce $\mathrm{Ca}^{2+}$ influx through VSCC to stimulate GH secretion (Wong et al. 1994b), presumably through phosphorylation of $\mathrm{Ca}^{2+}$ channels. Therefore, we speculate that the influx of extracellular $\mathrm{Ca}^{2+}$ through VSCC and subsequent activation of CAM kinase II may be downstream events mediating GH release after PACAP activation of the AC-cAMP-PKA and PLC-IP3-PKC pathways. Since PACAP has been reported to stimulate $\mathrm{Ca}^{2+}$ release from IP3-sensitive intracellular $\mathrm{Ca}^{2+}$ stores in some mammalian cell models (Hezareh et al. 1996), we do not exclude the possibility that mobilization of intracellular $\mathrm{Ca}^{2+}$ may also contribute to the $\mathrm{Ca}^{2+}$-dependent component of PACAPstimulated $\mathrm{GH}$ release in goldfish. In our pilot studies, PACAP-induced GH release from goldfish pituitary cells can be inhibited by the voltage-sensitive $\mathrm{Na}^{+}$channel blocker tetradotoxin (TTX; unpublished results, A.O.L. Wong). These results raise the possibility that VSCC activation in goldfish pituitary cells may occur as a consequence of membrane depolarization caused by the opening of TTXsensitive $\mathrm{Na}^{+}$channels (for a working model of PACAPstimulated $\mathrm{GH}$ release in the goldfish, see Fig. 5). In fish, PACAP cannot only influence GH release at the pituitary level, but can also play a role in regulation of $\mathrm{GH}$ synthesis. In the goldfish, ovine PACAP38 $(1 \mu \mathrm{M})$ increases steadystate GH mRNA levels in pituitary cells in a time-dependent manner (Fig. 6A). In our recent studies in grass carp pituitary cells, dopamine stimulates $\mathrm{GH}$ release via activation of pituitary D1 receptors (Wong et al. 1998c). In the same animal model, dopamine and ovine PACAP38 can stimulate GH release through a common cAMP- dependent pathway coupled to $\mathrm{Ca}^{2+}$ entry via VSCC (Leung et al. 1998). In this case, PACAP38 is also effective in increasing steady-state GH mRNA levels in grass carp pituitary cells in a dosedependent manner (Fig. 6B). This stimulatory action can be blocked by the PKA inhibitor H89 (Fig. 6C), suggesting that the influence of PACAP on GH synthesis is mediated through the AC-cAMP-PKA pathway. These results are also in accordance with previous findings that cis-acting elements responsive to cAMP induction, such as CRE (Wong et al. 1996a) and Pit-1 sites (Sekkali et al. 1999), have been identified in the $5^{\prime}$ promoter of fish $\mathrm{GH}$ genes.

\section{Conclusions}

First isolated in 1989, PACAP is known to be a novel peptide in mammals with a wide tissue distribution and it is involved in a variety of important biological functions. Although the physiological role of PACAP in lower vertebrates is largely unknown, evidence has accumulated to support the hypothesis that PACAP functions as a hypophysiotropic factor in fish. PACAP is expressed in the brain-pituitary axis of a few representative fish species. The molecular structure of fish PACAP is highly homologous to PACAPs reported in other vertebrates. The organization of PACAP gene in fish is similar to that of the mammalian counterpart, except that the preprohormone of fish PACAP 
also contains the amino acid sequence of fish GHRH. PACAP nerve fibers and PACAP receptors have been identified in the fish pituitary. In the goldfish, PACAP is stimulatory to GH and GTH-II secretion both in vivo and in vitro. The GH-releasing action of PACAP is mediated through pituitary $\mathrm{PACl}$ receptors coupled to the $\mathrm{AC}$ CAMP-PKA and PLC-IP3-PKC pathways. These signaling pathways may trigger $\mathrm{GH}$ release from goldfish pituitary cells by inducing extracellular $\mathrm{Ca}^{2+}$ entry through VSCC and subsequent CAM kinase II activation. PACAP is probably a physiological GH-releasing factor in fish as plasma GH levels in the goldfish can be reduced by a high dose of PACAP antagonist in vivo. In the same animal model, PACAP can interact with other $\mathrm{GH}$ regulators, including somatostatin, serotonin, and norepinephrine, to modulate $\mathrm{GH}$ release at the pituitary cell level. As a whole, these findings indicate that PACAP is produced within the hypothalamus of fish species and delivered to the pituitary to function as a regulator of pituitary hormone secretion. Although PACAP was demonstrated in our study to stimulate GTH-II release in fish, the receptor specificity for this stimulatory action has not been fully elucidated. The signal transduction mechanisms mediating this GTH-II releasing action are still unknown and clearly warrant further investigations. It is also worth mentioning that PACAP immunoreactivity has been identified in goldfish pituitary cells, and PACAP mRNA can be detected in the goldfish pituitary. These findings suggest that PACAP may be produced locally at the pituitary cell level to exert its biological functions. The functional role of PACAP as an autocrine and paracrine factor in the fish pituitary is still an unexplored area for future research.

\section{Acknowledgements}

The present study was sponsored by Research Grant Council (Hong Kong) and the Committee on Research and Travel Grants (University of Hong Kong) grants to A.O.L.W.and B.K.C.C. Support from Zoology Department (University of Hong Kong) in the form of postgraduate studentship (to M.Y.L. and L.Y.T.) is also acknowledged. Special thanks are given to Dr. R.E. Peter (University of Alberta, Canada) for the supply of GH standard and antiserum for GH RIA, Dr. W.K.K. Ho (Chinese University of Hong Kong, Hong Kong) for the supply of cDNA probes for $\mathrm{GH}$ mRNA quantitation, and Dr. W. Ge (Chinese University of Hong Kong, Hong Kong) for his technical advice in immunohistochemical staining. We are also grateful to Drs. K.L. Yu, D.K.O. Chan, F.C. Leung, W.W.M. Lee, and S.M. Chan for their support throughout the project.

\section{References}

Arimura, A. 1998. Perspectives on Pituitary adenylate cyclase activating polypeptide (PACAP) in the neuroendocrine, endocrine, and nervous sytems. Jpn. J. Physiol. 48: 301-331

Arimura, A., and Shioda, S. 1995. Pituitary adenylate cyclase polypeptide (PACAP) and its receptors: neuroendocrne and endocrine interaction. Front. Neuroendocrinol. 16: 53-88.

Arimura, A., Somogyvari-Vigh, A., Miyata, A., Mizuno, K., Coy, D.H., and Kitada, C. 1991. Tissue distribution of PACAP as de- termined by RIA: Highly abundant in the rat brain and testes. Endocrinology, 129: 2787-2789.

Balsa, J.A., Cacicedo, L., Lara, J.I., Lorenzo, M.J., Pazos, F., and Sanchex-Franco, F. 1996. Autocrine and/or paracrine action of vasoactive intestinal peptide on thyrotropin-releasing hormoneinduced prolactin release. Endocrinology, 137: 144-150.

Carlsson, P.O., Ostenson, C.G., Efendic, S., Langel, U., and Jansson, L. 1996. Pituitary adenylate cyclase activating polypeptide (PACAP) redistributes the blood within the pancreas of anesthetized rat. Regul. Pept. 63: 123-128.

Chartrel, N., Tonon, M.C., Vaudry, H., and Conlon, J.M. 1991. Primary structure of frog pituitary adenylate cyclase-activating polypeptide (PACAP) and effects of ovine PACAP on frog pituitary. Endocrinology, 129: 3367-3371.

Chan, K.W., Yu, K.L., Rivier, J., and Chow, B.K.C. 1998. Identification and characterization of a receptor from goldfish specific for a teleost growth hormone-releasing hormone-like peptide. Neuroendocrinology, 68: 44-56.

Chatterjee, T.K., Sharma, R.V., and Fisher, R.A. 1996. Molecular cloning of a novel variant of the pituitary adenylate cyclaseactivating polypeptide (PACAP) receptor that stimulates calcium influx by activation of L-type calcium channels. J. Biol. Chem. 271: $32226-32232$.

Chow, B.K.C. 1997. The goldfish vasoactive intestinal polypeptide receptor: Functional studies and tissue distribution. Fish Physiol. Biochem. 17: 213-222.

Chow, B.K.C., Yuen, T.T.H., and Chan, K.W. 1997. Molecular evolution of vertebrate VIP receptors and functional characterization of a VIP receptor from goldfish Carassius auratus. Gen. Comp. Endocrinol. 105: 176-185.

Couvineau, A., Rouyer-Fessard, C., Darmoul, D., Maoret, J.J., Carrero, I., Ogier-Denis, E., and Laburthe, M. 1994. Human intestinal VIP receptor : Cloning and functional expression of two cDNA encoding proteins with different $\mathrm{N}$-terminal domains. Biochem. Biophys. Res. Commun. 200: 769-776.

De Girolamo, P., Arcamone, N., Rosica, A., and Gargiulo, G. 1998. PACAP (Pituitary adenylate cyclase activating peptide)-like immunoreactivity in the gill arch of the goldfish, Carassius auratus: Distribution and comparison with VIP. Cell Tissue Res. 293: 567-571.

Dow, R.C., Bennie, J., and Fink, G. 1994. Pituitary adenylate cyclase-activating polypeptide-38 (PACAP38) is released into hypophysial portal blood in the male and female rat. J. Endocrinol. 142: R1-R4.

Filipsson, K., and Ahren, B. 1998. Protein kinase A inhibition and PACAP-induced insulin secretion in HIT-T15 cells. Ann. N.Y. Acad. Sci. 865: $441-444$.

Fradinger, E.A., Cummings, K.J., and Sherwood, N.M. 1996. GRF-PACAP gene in the zebrafish. In Program and Abstracts, the 2nd IUBS Symposium on Advances in the Molecular Endocrinology of Fish. 25-27 June 1996. Toronto, Canada. P5.

Ge, W., and Peter, R.E. 1994. Activin-like peptides in somatotrophs and activin stimulation of growth hormone release in goldfish. Gen. Comp. Endcocrinol. 95: 213-221.

Goth, M.I., Lyons, C.E., Canny, B.J., and Thorner, M.O. 1992. Pituitary adenylate cyclase activating polypeptide, growth hormone (GH)-releasing peptide and GH-releasing hormone stimulate GH release through distinct pituitary receptors. Endocrinology, 130: 939-944.

Gourlet, P., Vandermeers, A., Vandermeers-Piret, M.C., Rathe, J., De Neef, P., and Robberecht, P. 1995. Fragments of pituitary adenylate cyclase activating polypeptide discriminate between type I and II recombinant receptors. Eur. J. Pharmacol. 287: 7-11. 
Harmar, A.J., Arimura, A., Gozes, I., Journot, L., Laburthe, M., Pisegna, J.R., Rawlings, S.R., Robberecht, P., Said, S.I., Sreedharan, S.P., Wank, S.A., and Waschek, J.A. 1998. Nomenclature of receptors for vasoactive intestinal peptide (VIP) and pituitary adenylate cyclase activating polypeptide (PACAP). Pharmacol. Rev. 50: 265-570.

Harrington, M.E., Hoque, S., Hall, A., Golombek, D., and Biello, S. 1999. Pituitary adenylate cyclase activating peptide phase shifts circadian rhythms in a manner similar to light. $J$. Neurosci. 19: 6637-6672.

Hart, G.R., Gowing, H., and Burrin, J.M. 1992. Effects of a novel hypothalamic peptide, pituitary adenylate cyclase-activating polypeptide, on pituitary hormone release in rats. J. Endocrinol. 134: $33-41$.

Hezareh, M., Schlegel, W., and Rawlings, S.R. 1996. PACAP and VIP stimulate $\mathrm{Ca}^{2+}$ oscillation in rat gonadotrophs through PACAP /VIP type I receptor (PVR1) linked to a pertussis toxininsensitive G-protein and the activation of phospholipase C- $\beta$. J. Neuroendocrinology, 8: 367-374.

Hosoya, M., Kimura, C., Ogi, K., Ohkubo, S., Miyamota, Y., Kugoh, H., Shimizu, M., Onda, H., Oshimura, M., Arimura, A., and Fujino, M. 1992. Structure of the human pituitary adenylate cyclase activating polypeptide (PACAP) gene. Biochim. Biophys. Acta, 1129: 199-206.

Inagaki, N., Yoshida, H., Mizuta, M., Mizuno, N., Fujii, Y., Goni, T., Miyazaki, J., and Seino, S. 1994. Cloning and functional characterization of a third pituitary adenylate cyclase-activating polypeptide receptors subtype expressed in insulin-secreting cells. Proc. Natl. Acad. Sci. U.S.A. 91: 2679-2683.

Isobe, K., Nakai, T., and Takuwa, Y. 1993. $\mathrm{Ca}^{2+}$-dependent stimulatory effect of pituitary adenylate cyclase-activating polypeptide on catecholamine secretion from cultured porcine adrenal medullary chromaffin cells. Endocrinology, 132: 17571765.

Jiang, X.M., Wang, H.Y., Yu, J., and Ganea, D. 1998. VIP1 and VIP2 receptors but not PVR1 mediate the effect of VIP/PACAP on cytokine production in T lymphocytes. Ann. N.Y. Acad. Sci. 865: $397-407$

Jonsson, A.C. 1995. Galanin-, VIP-, and PACAP-like nerves in the Brockmann body of the cod Gadus morhua and the rainbow trout Oncorhynchus mykiss innervate the insulin- and glucagoncontaining cells. Neth. J. Zool, 45: 132-134.

Journot, L., Waeber, C., Pantaloni, C., Holsboer, F., Seeburg, P.H., Bockaert, J., and Spengler, D. 1995. Differential signal transduction by six splice variants of the pituitary adenylate cyclase-activating polypeptide (PACAP) receptor. Biochem. Soc. Trans. 23: 133-137.

Kah, O., Anglade, I., Lepretre, E., Dubourg, P., and De Monbrison, D. 1993. The reproductive brain in fish. Fish Physiol. Biochem. 11: $85-98$.

Kimura, C., Ohkubo, S., Ogi, K., Hosaya, M., Itoh, Y., Onda, H., Miyata, A., Jiang, L., Dahl, R.R., Stibbs, H.H., Arimura, A., and Fujino, M. 1990. A novel peptide which stimulates adenylate cyclase: Molecular cloning and characterization of the ovine and human cDNAs. Biochem. Biophys. Res. Commun. 166: 81-89.

Koves, K., Gorcs, T.J., Kausz, M., and Arimura, A. 1994. Present status of knowledge about the distribution and colocalization of PACAP in the forebrain. Acta Biologica Hungarica, 45: 297321.

Lauff, J.M., Modlin, I.M., and Tang, L.H. 1999. Biological relevance of pituitary adenylate cyclase-activating polypeptide 9PACAP) in the gastrointestinal tract. Regul. Pept. 84: 1-12.

Lee, E.K.Y., Chan, V.C.C., Chang, J.P., Yunker, W.K., and Wong,
A.O.L. 2000. Norepinephrine regulation of growth hormone release from goldfish pituitary cells. I. Involvement of $\alpha 2$ adrenoreceptor and interactions with dopamine and salmon gonadotropin-releasing hormone. J. Neuroendocrinol. 12: 311-322.

Leung, M.Y. 1999. Pituitary adenylate cyclase activating polypeptide as a novel growth hormone-releasing factor in the goldfish. M.Phil. thesis, University of Hong Kong, Hong Kong.

Leung, M.Y., Chang, J.P., Chow, B.K.C., and Wong, A.O.L. 1997. Pituitary adenylate cyclase activating polypeptide (PACAP) functions as a novel growth hormone $(\mathrm{GH})$-releasing factor in the goldfish. In Kawashima, S., and Kikuyama, S., editors. Advances in comparative endocrinology: Proceedings of the XIIIth international congress of comparative endocrinology; 1997 Nov 16-21; Yokohama, Japan. Bologna, Italy: Monduzzi Editore. pp. 681-686.

Leung, R.C.Y., Ng, S., Lee, E.K.Y., and Wong, A.O.L. 1998. Pituitary adenylate cyclase activating polypeptide- and dopamine D1-stimulated growth hormone release from grass carp pituitary cells are mediated through cAMP-dependent cascades coupled to extracellular $\mathrm{Ca}^{2+}$ entry via voltage-sensitive $\mathrm{Ca}^{2+}$ channels. In Program and Abstracts, the 11th Asia-Oceania Congress of Endocrinology. 23-24 Nov 1998. Seoul, Korea. p. 223.

Leung, M.Y., Chow, B.K.C., Yu, K.L., and Wong, A.O.L. $1999 a$. Molecular characterization, tissue distribution, and functional studies of PACAP in the goldfish. In Program and Abstract, the 5th International Congress of Comparative Physiology and Biochemistry. 23-28 Aug 1999. Calgary, Canada. Comp. Biochem. Physiol. 124A (Suppl.): S13-13.

Leung, M.Y., Tse, L.Y., Yu, K.L., Chow, B.K.C., and Wong, A.O.L. 1999b. Molecular cloning and tissue distribution of pituitary adenylate cyclase activating polypeptide in the goldfish. In Recent progress in molecular and comparative endocrinology. Edited by H.B. Kwon, J.M.P. Joss, and S. Ishii. Chonnam National University, Republic of Korea: HRC Press. pp. 383-388.

Li, M., Shuto, Y., Somogyvari-Vigh, A., and Arimura, A. 1999. Prohormone convertases 1 and 2 process proPACAP and generate matured, bioactive PACAP38 and PACAP27 in transfected rat pituitary GH4C1 cells. Neuroendocrinology, 69: 217-226.

Linden, A., Cardell, L.O., Yoshihara, S., and Nadel, J.A. 1999. Bronchodilation by pituitary adenylate cyclase-activating peptide and related peptides. Eur. Respir. J. 14: 443-451.

Lindholm, D., Skoglosa, Y., and Takei, N. 1998. Developmental regulation of pituitary adenylate cyclase activating polypeptide (PACAP) and its receptor I in rat brain: Function of PACAP as a neurotrophic factor. Ann. N.Y. Acad. Sci. 865: 189-196.

Luo, D., and Mckeown, B.A. 1991. Interaction of growth hormone-releasing factor and somatocrinin on in vitro release of growth hormone in rainbow trout (Oncorhynchus mykiss). Neuroendocrinology, 54: 359-364.

Marchant, T.A., Chang, J.P., Nahorniak, C.S., and Peter, R.E. 1989. Evidence that gonadotropin-releasing hormone alsofunctions as a growth hormone-releasing factor in the goldfish. Endocrinology, 124: 2509-2518.

Masuo, Y., Suzuki, N., Matsumoto, H., Tokito, F., Matsumoto, Y., Tsuda, M., and Fujino, M. 1993. Regional distribution of pituitary adenulate cyclase activating polypeptide (PACAP) in the rat central nervous system as determined by sandwich-enzyme immunoassay. Brain Res. 602: 57-63.

Matsuda, K., Arimura, A., Shioda, S., Takei, Y., Shimomura, H., and Uchiyama, M. 1997a. Pituitary adenylate cyclase-activating polypeptide (PACAP) in fishes: Purification, distribution, and physiological function. In Kawashima, S., and Kikuyama, S., editors. Advances in comparative endocrinology: Proceedings of 
the XIIIth international congress of comparative endocrinology; 1997 Nov 16-21; Yokohama, Japan. Bologna, Italy: Monduzzi Editore. pp. 687-691.

Matsuda, K., Takei, Y., Katoh, J.I., Shioda, S., Arimura, A., and Uchiyama, M. 1997b. Isolation and structural characterization of pituitary adenylate cyclase activating polypeptide (PACAP)-like peptide from the brain of a teleost, stargazer, Uranoscopus japonicus. Peptides (Tarrytown, N.Y.), 18: 723-727.

Matsuda, K., Itoh, Y., Yoshida, T., Shioda, S., Arimura, A., and Uchiyama, M. 1998a. The localization of pituitary cyclase activating polypeptide (PACAP)-like immunoreactivity in the hypothalamo-pituitary region of an elasmobranch, stingray, Dasyatis akajei. Peptides (Tarrytown, N.Y.), 19: 1263-1267.

Matsuda, K., Yoshida, T., Nagano, Y., Kashimoto, K., Yatohgo, T., Shimomura, H., Shioda, S., Arimura, A., and Uchiyama, M. 1998b. Purification and primary structure of pituitary adenylate cyclase activating polypeptide (PACAP) from the brain of elasmobrance, stingray, Dasyatis akajei. Peptides (Tarrytown, N.Y.), 19: 1489-1495.

McArdle, C.A., and Counis, R. 1996. GnRH and PACAP actions in gonadotrophs : Cross-talk between phospholipase $\mathrm{C}$ - and adenylate cyclase-mediated signaling pathways. Trends Endocrinol. Metab. 7: 168-175.

McRory, J., and Sherwood, N.M. 1997. Two protochordate genes encode pituitary adenylate cyclase activating polypeptide and related family members. Endocrinology, 138: 2380-2390.

McRory, J.E., Parker, D.B., Ngamvongchon, S., and Sherwood, N.M. 1995. Sequence and expression of cDNA for pituitary adenylate cyclase activating polypeptide (PACAP) and growth hormone-releasing hormone (GHRH)-like peptide in catfish. Mol. Cell. Endocrinol. 108: 169-177.

McRory, J.E., Parker, R.L., and Sherwood, N.M. 1997. Expression and alternative processing of a chicken gene encoding both growth hormone-releasing hormone and pituitary adenylate cyclase-activating polypeptide. DNA Cell Biol. 16: 95-102.

Miyata, A., Arimura, A., Dahl, D.H., Minamino, N., Uehara, A., Jiang, L., Culler, M.D., and Coy, D.H. 1989. Isolation of a novel 38 residue hypothalamic peptide which stimulates adenylate cyclase in pituitary cells. Biochem. Biophys. Res. Commun. 164: $567-574$.

Miyata, A., Dah, D.H., Jiang, L., Kitada, K., Fujino, M, Minamino, N., and Arimura, A. 1990. Isolation of a neuropeptde corresponding to the $\mathrm{N}$-terminal 27 residues of the pituitary adenylate cyclase activating polypeptide with 38 residues (PACAP38). Biochm. Biophys. Res. Commun. 170: 643-648.

Montero, M., Yon, L., Rousseau, K., Arimura, A., Fournier, A., Dufour, S., and Vaudry, H. 1998. Distribution, characterization, and growth hormone-releasing activity of pituitary adenylate cyclase activating polypeptide in the European eel, Anguilla anguilla. Endocrinology, 139: 4300-4310.

Murakami, Y., Koshimura, K., Yamauchi, K., Nishiki, M., Tanaka, J., Furuya, H., Miyake, T., and Kato, Y. 1995. Pituitary adenylate cyclase activating polypeptide (PACAP) stimulates growth hormone release from GH3 cells through type II PACAP receptor. Regul. Pept. 56: 35-40.

Ogi, K., Kimura, C., Onda, H., Arimura, A., and Fujino, M. 1990. Molecular cloning and characterization of the cDNA for the precursor of rat pituitary adenylate cyclase-activating polypeptide (PACAP). Biochem. Biophys. Res. Commun, 173: 1271-1279.

Ogi, K., Miyamoto, Y., Masuda, Y., Habata, Y., Hosoya, M., Ohtaki, T., Masuo, Y., Onda, H., and Fujion, M. 1993. Molecular cloning and functional expression of a cDNA encoding the human pituitary adenylate cyclase activating polypeptide receptor. Biochem. Biophys. Res. Commun. 196: 1511-1521.
Ohkubo, S., Kimura, C., Ogi, K., Okazaki, K., Hosaya, M., Onda, H., Miyata, A., Arimura, A., and Fujino, M. 1992. Primary structure and characterization of the precursor to human pituitary adenylate cyclase activating polypeptide. DNA Cell Biol. 11: $21-30$.

Okazaki, K., Itoh, Y., Ogi, K., Ohkubo, S., and Onda, H. 1995. Characterization of murine PACAP mRNA. Peptides (Tarrytown, N.Y.), 16: 1295-1299.

Olsson, C., and Holmgren, S. 1994. Distribution of PACAP (pituitary adenylate cyclase activating polypeptide)-like and helospectin-like peptides in the teleost gut. Cell Tissue Res. 277 . 539-547.

Olsson, C., and Holmgren, S. 1998. PACAP inhibits spontaneous contractions in the intestine of the Atlantic cod, Gadus morhua. Ann. N.Y. Acad. Sci. 865: 512-514.

Pantaloni, C., Brabet, P., Bilanges, B., Dumuis, A., Houssami, S., Spengler, D., Bockaert, J., and Journot, L. 1996. Alternative splicing in the N-terminal extracellular domain of the pituitary adenylate cyclase-activating polypeptide (PACAP) receptor modulates receptor selectivity and relative potencies of PACAP27 and PACAP38 in phospholipase C activation. J. Biol. Chem. 271: 22146 - 22151.

Park, S.Y., Choi, H.J., and Hwang, O. 1999. Regulation of basal expression of catecholamine-synthesizing enzyme genes by PACAP. Mol. Cells, 9: 146-351.

Parker, D.B., Coe, I.R., Dixon, G.H., and Sherwood, N.M. 1993. Two salmon neuropeptides encoded by one brain cDNA are structurally related to members of the glucagon superfamily. Eur. J. Biochem. 215: 439-448.

Parker, D.B., Power, M.E., Swanson, P., Rivier, J., and Sherwood, N.M. 1997. Exon skipping in the gene encoding pituitary adenylate cyclase-activating polypeptide in salmon alters the expression of two hormones that stimulate growth hormone release. Endocrinology, 138: 414-423.

Peter, R.E., Nahorniak, C.S., Vale, W.W., and Rivier, J.E. 1984. Human pancreatic growth hormone-releasing factor (hpGRF) stimulates growth hormone release in goldfish. J. Exp. Zool. 231: 161-163.

Pisegna, J.R., and Wank, S.A. 1993. Molecular cloning and functional expression of the pituitary adenylate cyclase-activating polypeptide type I receptor. Proc. Natl. Acad. Sci. U.S.A. 90: $6345-6349$.

Propato-Mussafiri, R., Kanse, S.M., Ghatei, M.A., and Bloom, S.R. 1992. Pituitary adenylate cyclase activating polypeptide releases 7B2, adenocorticotropin, growth hormone, and prolactin from the mouse and rat clonal pituitary cell lines AtT-20 and GH3. J. Endocrinol. 132: 107-113.

Rao, S.D., Prasada Rao, P.D., and Peter, R.E. 1996. Growth hormone-releasing hormone immunoreactivity in the brain, pituitary, and pineal of the goldfish, Carassius auratus. Gen. Comp. Endocrinol. 102: 210-220.

Rawlings, S.R. 1994. PACAP, PACAP receptors, and intracellular signalling. Mol. Cell. Endocrinol. 101: C5-C9.

Rawlings, S.R., and Hezareh, M. 1996. Pituiaty adenylate cyclase activating polypeptide (PACAP) and PACAP/vasoactive intestinal polypeptide receptors: Actions on the anterior pituitary gland. Endocr. Rev. 17: 4-29.

Rawlings, S.R., Piuz, I., Schlegel, W., Bockaert, J., and Journot, L. 1995. Differential expression of pituitary adenylate cyclaseactivating polypeptide/vasoactive intestinal polypeptide receptor subtypes in clonal pituitary somatotrophs and gonadotrophs. Endocrinology, 136: 2088-2098.

Reid, S.G., Fritsche, R., and Jonnson, A.C. 1995 Immunohistochemical localization of bioactive peptides and 
amines associated with the chromaffin tissue of five species of fish. Cell Tissue Res. 280: 499-512.

Schomerus, E., Puch, A., Bunting, R., Mason, W.T., and McArdle, C.A. 1994. Effects of pituitary adenylate cyclase-activating polypeptide in the pituitary; Activation of two signal transduction pathways in the gonadotrope-derived $\alpha \mathrm{T} 3-1$ cell line. Endocrinology, 134: 315-323.

Sekkali, B., Belayew, A., Bortolussi, M., Martial, J.A., and Muller, M. 1999. Pit-1 mediates cell-specific and cAMP-induced transcription of the tilapia GH gene. Mol. Cell. Endocrinol. 152: 111-123.

Sherwood, N.M., Parker, D.B., McRory, J.E., and Lescheid, D.W. 1994. Molecular evolution of growth hormone-releasing hormone and gonadotropin-releasing hormone. In Fish physiology, Vol. 13. Edited by C.L. Hew and N.M. Sherwood. New York: Academic Press. pp. 3-66.

Spengler, D., Waeber, C., Pantaloni, C., Holsboer, F., Bocaert, J., Seeburg, F.H., and Journot, L. 1993. Differential signal transduction by five splice variants of the PACAP receptor. Nature (London), 365: 170-175.

Svoboda, M., Tastenoy, M., Rampelbergh, J.V., Goossens, J.F., De Neef, P., Waelbroeck, M., and Robberecht, P. 1994. Molecular cloning and functional characterization of a human VIP receptor from SUP-T1 lymphoblasts. Biochem. Biophys. Res. Commun. 205: 1617-1624.

Takahashi, K., Totsune, K., Murakami, O., Satoh, F., Sone, M., Ohneda, M., Sasano, H., and Mouri, T. 1994. Pituitary adenylate cyclase activating polypeptide (PACAP)-like immunoreactivity in human hypothalamus: co-localization with arginine vasopressin. Regul. Pept. 50: 267-275.

Tanaka, K., Shibuya, I., Uezono, Y., Ueta, Y., Toyohira, Y., Yanagihara, N., Izumi, F., Kanno, T., and Yamashita, H. 1998. Pituitary adenylate cyclase-activating polypeptide causes $\mathrm{Ca}^{2+}$ release from ryanodine/caffeine stores through a novel pathway independent of both inositol trisphosphates and cyclic AMP in bovine adrenal medullary cells. J. Neurochemistry, 70: 16521661 .

Tse, L.Y. 1999. Identification of a novel PHI receptor in goldfish Carassius auratus: Implications of conservation of PHI structure in vertebrates. M.Phil. thesis, University of Hong Kong, Hong Kong.

Tse, L.Y., Leung, M.Y., Wong, A.O.L., Yu, K.L., and Chow, B.K.C. 1997. Evolution and tissue distribution of goldfish vasoactive intestinal peptide and peptide histidine isoleucine. In Kawashima, S., and Kikuyama, S., editors. Advances in comparative endocrinology: Proceedings of the XIIIth international congress of comparative endocrinology; 1997 Nov 16-21; Yokohama, Japan. Bologna, Italy: Monduzzi Editore. pp. 655-660.

Tsujii, T., Ishizaka, K., and Winters, S.J. 1994. Effects of pituitary adenylate cyclase activating polypeptide on gonadotropin secretion and subunit messenger ribonucleic acids in perifused rat pituitary cells. Endocrinology, 135: 826-833.

Uesaka, T., Yano, K., Yamasaki, M., and Ando, M. 1995. Somatostatin-, vasoactive intestinal peptide-, and granulin-like peptides isolated from intestinal extracts of goldfish, Carassius auratus. Gen. Comp. Endocrinol. 99: 298-306.

Wei, L., Chan, W.W.S., Butler, B., and Cheng, K. 1993. Pituitary adenylate cyclase activating polypeptide-induced desensitization on growth hormone release from rat primary pituitary cells. Biochem. Biophys. Res. Commun. 197: 1396-1401.

Wei, Y., Martin, S.C., Heinrich, G., and Mojsov, S. 1998. Cloning and functional characterization of PACAP-specific receptors in zebrafish. Ann. N.Y. Acad. Sci. 865: 45-48.
Wong, A.O.L., Chang, J.P., and Peter, R.E. 1993. Interactions of somatostatin, gonadotropin-releasing hormone, and the gonads on dopamine-stimulated growth hormone release in the goldfish. Gen. Comp. Endocrinol. 92: 366-378.

Wong, A.O.L., Van der Kraak, G., and Chang, J.P. 1994a. Cyclic 3',5'adenosine monophosphate mediates dopamine D1-stimulated growth hormone release from goldfish pituitary cells. Neuroendocrinology, 60: $410-417$.

Wong, A.O.L., Van Goor, F., Jobin, R.M., Neumann, C.M., and Chang, J.P. $1994 b$. Interactions of cyclic adenosine 3',5'-monophosphate, protein kinase $\mathrm{C}$, and calcium in dopamine- and gonadotropinreleasing hormone-stimulated growth hormone release in the goldfish. Endocrinology, 135: 1593-1604.

Wong, A.O.L., Le Drean, Y., Liu, D., Hu, Z.Z., Du, S.J., and Hew, C.L. 1996a. Induction of Chinook salmon growth hormone promoter activity by the adenosine $3^{\prime}, 5^{\prime}$-monophosphate (cAMP)dependent pathway involves two cAMP-response elements with the CGTCA motif and the pituitary-specific transcription factor Pit-1. Endocrinology, 137: 1775-1784.

Wong, A.O.L., Leung, M.Y., Shea, W.L.C., and Chow, B.K.C. 1996 b. Pituitary adenylate cyclase activating polypeptide (PACAP) stimulates growth hormone release from goldfish pituitary cells through PACAP type I receptors. In Program \& Abstracts, the 2nd IUBS Symposium on Advances in the Molecular Endocrinology of Fish. 25-27 June 1996. Toronto, Canada. P40.

Wong, A.O.L., Leung, M.Y., Shea, W.L.C., Tse, L.Y., Chang, J.P., and Chow, B.K.C. 1998a. Hypophysiotropic action of pituitary adenylate cyclase activating polypeptide (PACAP) in the goldfish: Immunohistochemical demonstration of PACAP in the pituitary, PACAP stimulation of growth hormone release from pituitary cells, and molecular cloning of pituitary type I PACAP receptor. Endocrinology, 139: 3465-3476.

Wong, A.O.L., Murphy, C.K., Chang, J.P., Neurmann, C.M., Lo, A., and Peter, R.E. 1998b. Direct actions of serotonin on gonadotropin-II and growth hormone release from goldfish pituitary cells : Interactions with gonadotropin-releasing hormone and dopamine and further evaluation of serotonin receptor specificity. Fish Physiol. Biochem. 19: 23-34.

Wong, A.O.L., Ng, S., Lee, E.K.Y., Leung, R.C.Y., and Ho, W.K.K. 1998c. Somatostatin inhibits (D-Arg ${ }^{6}$, Pro ${ }^{9}$-Net) salmon gonadotropin-releasing hormone- and dopamine D1-stimulated growth hormone release from perifused pituitary cells of Chinese grass carp, Ctenopharyngodon idellus. Gen. Comp. Endocrinol. 110: 29-45.

Wray, V., Kakoschke, C., Nokihara, K., and Naruse, S. 1993. Solution structure of pituitary adenylate cyclase activating polypeptide by nuclear magnetic resonance spectroscopy. Biochemistry, 32: 5832-5841.

Wray, V., Nokihara, K., and Naruse, S. 1998. Solution structure comparison of the VIP /PACAP family of peptides by NMR spectroscopy. Ann. N.Y. Acad. Sci. 865: 37-44.

Vaughan, J.M., Rivier, J., Spiess, J., Peng, C., Chang, J.P., Peter, R.E., and Vale, W. 1993. Isolation and characterization of hypothalamic growth hormone releasing factor from common carp, Cyprinus carpio. Neuroendocrinology, 56: 529-534.

Yasuhara, T., Mizuno, K., Somogyvari-Vigh, A., Komaki, G., and Arimura, A. 1992. Isolation and primary structure of chicken PACAP. Regul. Pept. 37: 326.

Zhong, Y., and Kasson, B.G. 1994. Pituitary adenylate cyclase activating polypeptide stimulates steroidogenesis and adenosine 3',5'-monphosphate accumulation in cultured rat granulosa cells. Endocrinology, 135: 207-213. 